\title{
Beneficial management practices and mitigation of greenhouse gas emissions in the agriculture of the Canadian Prairie: a review
}

\author{
Haben Asgedom • Ermias Kebreab
}

Accepted: 17 September 2010 / Published online: 17 March 2011

(C) The Author(s) 2011. This article is published with open access at Springerlink.com

\begin{abstract}
Climate change is one of the main global issues of modern time. Ever increasing demand for food/feed and the need for higher environmental standards require shaping of the agricultural activities toward ecological and more sustainable efficient systems. One of the principal ways of attaining higher productivity and environmental standards is identification and adoption of beneficial management practices (BMP) by reviewing the conventional agricultural activities. The BMP are agricultural practices that promote sustainable land stewardship and maintain/increase profitability of farms. The BMP are from both crop and animal production systems and tradeoffs between the two systems could provide several opportunities in reducing, removing and/or avoiding of greenhouse gases (GHG) emissions. Despite that, few reviews have presented them together. This review covers GHG emissions related to the BMP in the crop and animal production systems of farms relevant to Canadian Prairie. These BMP include: (1) use of inorganic $\mathrm{N}$ fertilizers, (2) livestock and feed management, (3) manure management, (4) cropping systems, (5) tillage practices and (6) improved pasture and grazing management. In addition, sources of variations, quantification methods and adoptability are discussed. Quantified GHG emissions from direct and indirect measurements of researches from Canada and other part of the world are included. Since most experiments are conducted under multiple biophysical scenarios while adopting various
\end{abstract}

\footnotetext{
H. Asgedom

Department of Soil Science, University of Manitoba,

Winnipeg, Manitoba R3T 2N2, Canada

e-mail: asgedomt@cc.umanitoba.ca

E. Kebreab $(\bowtie)$

Department of Animal Science, University of California,

Davis, CA 95616, USA

e-mail: ekebreab@ucdavis.edu
}

methodologies, summarizing the findings was difficult. The effect of BMP on GHG is determined by ecological processes. Such determinants are discussed and knowledge gaps are identified. Integration of crop and livestock production systems could further lead toward higher energy and resource use efficiency; hence less GHG emissions.

Keywords BMP.Canadian Prairie - Cropping systems · $\mathrm{GHG} \cdot$ Livestock $\cdot$ Pasture

\section{Contents}

1. Introduction . . . . . . . . . . . . . 2

2. Inorganic nitrogen fertilizers $\ldots \ldots \ldots \ldots \ldots$

2.1. Conventional inorganic nitrogen fertilizers .... 3

2.2. $\mathrm{N}$ fertilizers formulations - nitrification/urease inhibitors and enhanced efficiency fertilizers . . . 5

2.3. Rate, placement and timing options ....... 5

3. Livestock . . . . . . . . . . . . . 6

3.1. Enteric fermentation . . . . . . . . . 6

3.1.1. Feeding management ........... 7

3.1.2. Forage: grain ratio and restricted feed intake ............. 8

3.1.3. Nutritional manipulations. . . . . . . . . 8

3.1.4. Growth promoters, ionophores, and organic acids ............... . . . . .

3.1.5. Feed processing ........... . . . . . . . . .

3.1.6. Genetic selection ............ . 9

3.2. Manure . . . . . . . . . . . . . . . . 99

3.3. Greenhouse gases emissions from manure applied soil . . . . . . . . . . . . . . 9

3.4. Net greenhouse gases emissions from animal agriculture . . . . . . . . . . 10

4. Cropping systems . . . . . . . . . . . . . 10

4.1. Inclusion of pulses . . . . . . . . . . . . 11

4.2. Rotational forage . . . . . . . . . . . . 11 
4.3. Cover crops . . . . . . . . . . . . . . . 12

4.4. Tillage . . . . . . . . . . . . . . . 12

5. Pasture management . . . . . . . . . . . . . 13

5.1. Permanent cover . . . . . . . . . . . . . . 13

5.2. Grazing management . . . . . . . . . . . 13

6. Intergration of crop-livestock systems . . . . . . . . 14

7. Biofuel . . . . . . . . . . . . . . . . . . . . . . . 14

8. Boundaries of net greenhouse gases computations and limitations .................... 14

9. Conclusions . . . . . . . . . . . . . . . 15

10. References ................... 15

\section{Introduction}

The major causes of global warming are greenhouse gases (GHG) emitted to the atmosphere and the most common GHG in agriculture are nitrous oxide $\left(\mathrm{N}_{2} \mathrm{O}\right)$, methane $\left(\mathrm{CH}_{4}\right)$ and carbon dioxide $\left(\mathrm{CO}_{2}\right)$. These forms of chemicals have various potency of global warming potentials for 100 years (i.e. $\mathrm{N}_{2} \mathrm{O}$ (298), $\mathrm{CH}_{4}$ (25) and $\mathrm{CO}_{2}$ (1)) (Foster et al. 2007) and are usually expressed to the equivalence potency of global warming potential of $\mathrm{CO}_{2}\left(\mathrm{CO}_{2} \mathrm{e}\right)$. The global technical mitigation potential from agriculture, excluding fossil fuel offsets from biomass by 2030, considering all gases is estimated at approximately 5500-6000 $\mathrm{Mt} \mathrm{CO}_{2} \mathrm{e}$ year ${ }^{-1}$. In 2008, about $37 \mathrm{Mt} \mathrm{CO}_{2} \mathrm{e}$ of the net emissions from agriculture were from $\mathrm{N}_{2} \mathrm{O}$, with the remaining $25 \mathrm{Mt} \mathrm{CO}_{2} \mathrm{e}$ coming from $\mathrm{CH}_{4}$ (Environment Canada 2010). On the other hand, through photosynthesis and carbon sequestration agriculture is a net sink for $\mathrm{CO}_{2}$ emissions (Smith et al. 2008a).

In accordance with the Kyoto protocol, Canada has to reduce its emissions, in various economic sectors, to $6 \%$ below the 1990 levels between the 2008 and 2012. The onfarm management practice is one of these economic sectors (Desjardins et al. 2001). Agricultural related GHG emissions in 1990 totalled 89.9 $\mathrm{Mt} \mathrm{CO}_{2} \mathrm{e}$ (Kulshreshtha et al. 2000) and about half of this came from soils amended with manure (Kebreab et al. 2006) and the rest from livestock, application of $\mathrm{N}$ fertilizers and other farm activities. The emissions from Canadian agricultural activities are estimated to increase to $97 \mathrm{Mt} \mathrm{CO}_{2} \mathrm{e}$, mainly due to increased livestock production and off-farm transportation/storage, by 2010 (Kulshreshtha et al. 2000).

The Canadian Prairie includes the provinces of Manitoba, Saskatchewan, and Alberta. In 2006, the farm land area under agricultural production was estimated at 54.8 million ha. Most of the farms in the Canadian Prairie have specialized either in crop or livestock production systems. In 2006, $46 \%$ of the farms were operating on crop production and $51 \%$ on livestock production
(Statistics Canada 2006). The main crops are wheat, oilseed, pulse and other grains. Beef, hog and dairy are the major animals in the livestock production. It is widely believed that the numbers of farms that integrate crop and livestock production systems are very small.

Rochette et al. (2008) estimated the mean $\mathrm{N}_{2} \mathrm{O}$ emission of the Canadian Prairie from 1990 to 2005 using the Intergovernmental Panel on Climate Change (IPCC) country-specific methodologies (Tier I and Tier II). The emissions were grouped according to sources as follows: $\mathrm{N}$ fertilizer (9.21), manure (1.52), crop residue (6.06), change perennial to annual crops $(0.19)$, soil tillage practices $(-1.48)$, summer fallow (2.14), organic soil (0.01), moist landscape (2.08), grazing animals (4.62), irrigation (0.61), all soils sources (24.99), animal waste management (5.04) and indirect sources (6.27). The total agricultural emission was estimated at $36.3 \mathrm{Gg} \mathrm{N}_{2} \mathrm{O}-\mathrm{N}$. On the other hand, the main sources of $\mathrm{CH}_{4}$ emission are from ruminant animals, flooding, animal waste management and biomass burning (Mosier et al. 1998). In 2002, $\mathrm{CH}_{4}$ emission was estimated at $26 \%$ of the total agricultural emission (Kebreab et al. 2006). In addition, most agricultural lands have lost their antecedent soil organic carbon pools, which is estimated to range from 20 to $60 \mathrm{Mg} \mathrm{C}$ ha $^{-1}$ (Lal 2001).

To reverse these trends, several GHG mitigation technologies in both crop and animal production systems of farms have been recommended and generally the technologies can be categorized into three main components. These are reducing emissions, enhancing removals and avoiding (displacing) emissions (Smith et al. 2008a). In agriculture, the practices are commonly known as beneficial management practices (BMP).

BMP can promote good land stewardship and sustain or increase net economic return and they have been recommended to reduce global warming potential by several researchers from Canada and other parts of the world (e.g. Desjardins et al. 2001; Adviento-Borbe et al. 2007; Johnson et al. 2007; Christopher and Lal 2007; Snyder et al. 2007). $\mathrm{BMP}$ are reported to improve $\mathrm{C}$ sequestration, reduce $\mathrm{N}$ losses to the environment (Jayasundara et al. 2007) and minimize aggregate stressors (i.e. nutrients, pesticides and sediments) to water bodies (Yates et al. 2007).

Some of the potential BMP (Fig. 1) include (1) proper selection/use of $\mathrm{N}$ fertilizer (source, rate, placement and timing), (2) application of nitrification/urease inhibitors or coated N fertilizers (Snyder et al. 2007), (3) Livestock feed management and mitigation of $\mathrm{CH}_{4}$ from ruminants (Kebreab et al. 2006) as well as improve manure management (MAFRI 2005), (4) intensive cropping systems (Adviento-Borbe et al. 2007) including leguminous cover crops (Christopher and Lal 2007) and tillage practices (Wagner-Riddle et al. 2007), and (5) improvement of pasture, grazing practices and forage management (Soussana et al. 2007). 


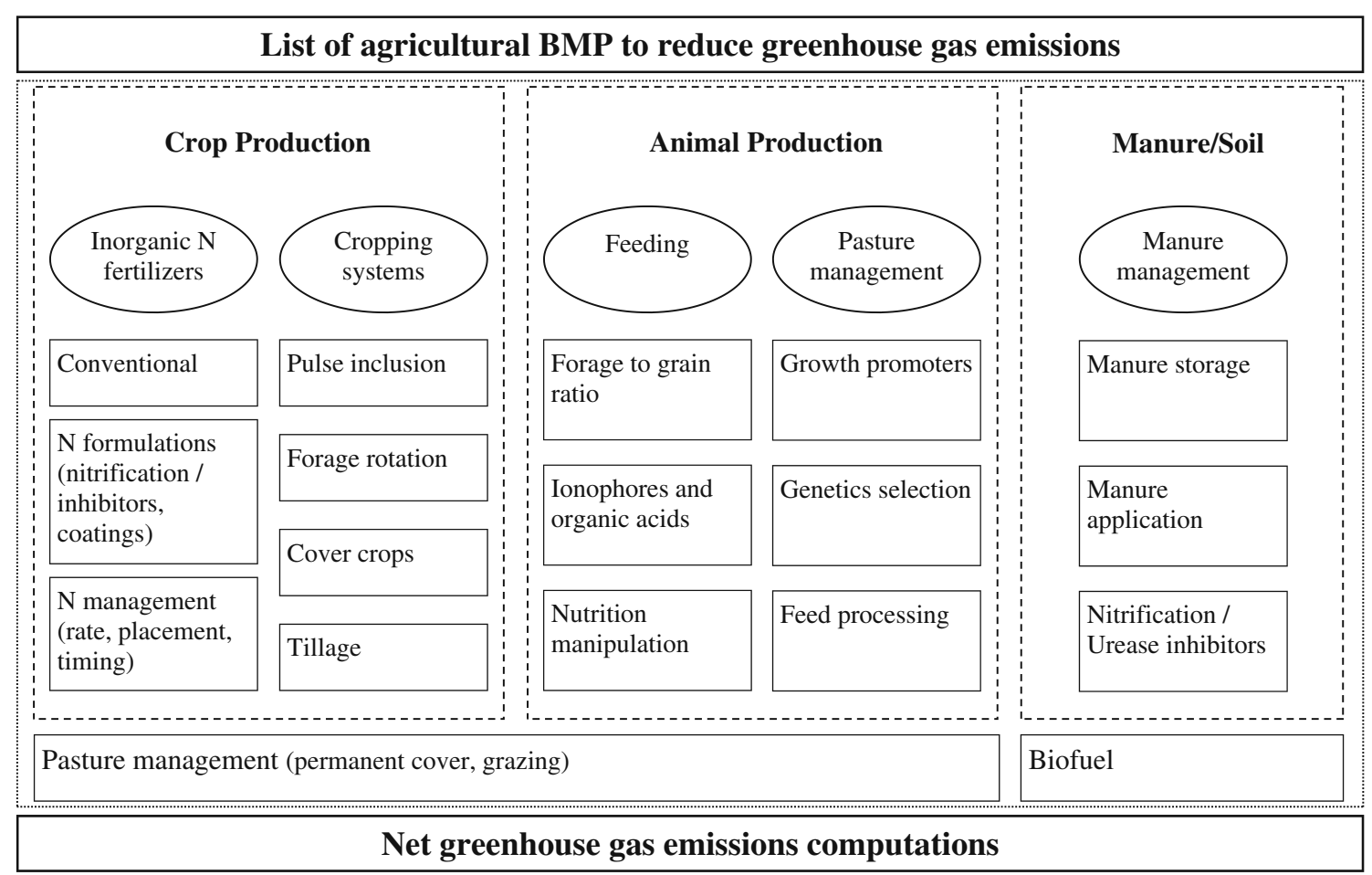

Fig. 1 List of agricultural beneficial management practices (BMP) to reduce GHG emissions from the Canadian Prairie

The main objective of the review is to evaluate and summarize the GHG mitigation potential of the BMP in the cropping and animal production systems of the Canadian Prairie.

\section{Inorganic nitrogen fertilizers}

The ultimate goal of $\mathrm{N}$ fertilizer application to soils is to increase the yield and enhance the soil $\mathrm{N}$ contents. Plants' nutrient uptake is time dependent and mostly relies on the chemical availability and positional accessibility of the nutrient to the plant roots, when demanded. However, $\mathrm{N}$ is highly mobile and when $\mathrm{N}$ enters the soil solution from fertilizers, it undergoes various reactions that may lead to immobilization, leaching, volatilization, and denitrification. Notably, the potential of soil to increase $\mathrm{N}_{2} \mathrm{O}$ emission from $\mathrm{N}$ fertilizers is high (Rochette et al. 2008). Agronomic studies, therefore, have been targeting to optimize the selection of source, timing and methods of application to reduce such losses. Agricultural researchers are focusing on inter-seasonal plant requirement and site-specific biophysical conditions to reduce GHG emissions and costs. The outcome of such studies, in the Canadian Prairie and other parts of world, are discussed below.

Generally, the application of $\mathrm{N}$ fertilizer increases the $\mathrm{N}$ related emissions. However, biomass gains from the applications can reduce the net GHG emissions. There are contradicting research findings from long-term wheat-fallow rotation with $\mathrm{N}$ application on inherently organic rich soils of Alberta, where soil carbon was lost instead of sequestered (Bremer et al. 1994). Christopher and Lal (2007) summarized the causes that increase or decrease soil sequestration by $\mathrm{N}$ application. Soil organic carbon can increase if: (1) the crop yield and amount of crop residue is enhanced, (2) the soil is coarser in texture, (3) the soil is under no-tillage and (4) the climate is temperate. On the other hand, soil organic carbon can decrease if (1) the soil is already rich in soil organic content (e.g. Canadian Chernozems), (2) the soil is finer textured, (3) the climate is tropical and (4) the fertilizer application rate exceeds the crop $\mathrm{N}$ demand. The relevant BMP in mineral fertilizers management are summarized in Table 1. Application of $\mathrm{N}$ fertilizers at the right rate is given the highest priority whereas proper selection of sources of $\mathrm{N}$ is ranked in the second place and placement at the right position as well as timing of application are recommended for further studies to mitigate GHG emissions.

\subsection{Conventional inorganic nitrogen fertilizers}

It is estimated that $74 \%$ of the farms in the Canadian Prairie use inorganic $\mathrm{N}$ fertilizers (Lefebvre et al. 2005). The cost of fertilizer has a significant influence on the choice type and quantity of N fertilizer (Statistics Canada 2004). Since 1999, the cost of inorganic $\mathrm{N}$ fertilizer has been increasing but in the last few years it has accelerated. Urea has increased by $\$ 50 \mathrm{t}^{-1}$ and ammonia by $\$ 900 \mathrm{t}^{-1}$. On average, one cent increase in purchasing price is estimated to cost 
Table 1 Beneficial management practices (BMP) related to $\mathrm{N}$ fertilizer management, recommended for the province of Manitoba to reduce the GHG emission and increase the environmental stewardship (modified after Eco-ressources Consultants 2009)

\begin{tabular}{|c|c|c|c|c|}
\hline BMP & Emission reduction potential & Side effects/Co-benefits/barriers & Knowledge gaps & Recommendations \\
\hline $\begin{array}{l}\text { Fertilizer quantity } \\
\text { (right rate) }^{\mathrm{a}}\end{array}$ & $\begin{array}{l}\text { Reduce fertilizer use and } \\
\text { reduce } \mathrm{N}_{2} \mathrm{O} \text { emissions }\end{array}$ & $\begin{array}{l}\text { Improves water quality, reduced } \\
\text { fertilizer use, greater economic } \\
\text { returns and risk of yield reduction }\end{array}$ & $\begin{array}{l}\text { More research needed to } \\
\text { establish optimum rates }\end{array}$ & $\begin{array}{l}\text { Highly } \\
\text { recommended }\end{array}$ \\
\hline $\begin{array}{l}\text { Source of } \mathrm{N} \text { fertilizer } \\
\text { (Right product) }^{\mathrm{b}}\end{array}$ & $\begin{array}{l}\text { Increase nutrient use } \\
\text { efficiency and inhibitors } \\
\text { further reduce } \mathrm{N}_{2} \mathrm{O} \\
\text { emission }\end{array}$ & $\begin{array}{l}\text { Adoption may be limited; less } \\
\text { leaching to the ground water }\end{array}$ & $\begin{array}{l}\text { New } \mathrm{N} \text { formulations using } \\
\text { inhibitors and coatings are } \\
\text { untested in the Canadian Prairie }\end{array}$ & Recommended \\
\hline $\begin{array}{l}\text { Fertilizer placement } \\
\text { (Right place) }^{\mathrm{a}}\end{array}$ & $\begin{array}{l}\text { Affected by sources of } \mathrm{N} \\
\text { fertilizers, unproven when } \\
\text { interacted with sources } \\
\text { of } \mathrm{N} \text {, reduce fertilizer use }\end{array}$ & $\begin{array}{l}\text { Requires high level of monitoring; } \\
\text { knowledge and equipment needed; } \\
\text { co-benefits include water and air } \\
\text { quality, and reduced fertilizer use }\end{array}$ & $\begin{array}{l}\text { Untested in the } \\
\text { Canadian Prairie }\end{array}$ & $\begin{array}{l}\text { Not recommendec } \\
\text { as immediate } \\
\text { mitigation } \\
\text { practice }\end{array}$ \\
\hline
\end{tabular}

${ }^{a}$ Snyder et al. (2007); Desjardins et al. (2001); Grant et al. (2004)

${ }^{\mathrm{b}}$ Grant et al. (2004); Liebig et al. (2005); Snyder et al. (2007); Tenuta and Beauchamp (2003); Walters (2005); Malhi and Lemke (2007); Stehfest and Bouwman (2006)

Canadian farmers $\$ 61$ million. For instance, in Manitoba, $70 \%$ to $98 \%$ of all fertilizers are applied in the spring; this can create huge demand-supply gap, thus affecting a price (Rolfe 2007). The average price difference of urea, anhydrous ammonia and urea ammonium nitrate (UAN) solution in fall and spring between the years 2001 to 2006 was estimated at $12 \%, 17 \%$ and $7 \%$, respectively (MAFRI 2008). Generally, in the Prairie, some farmers apply during fall to minimize the fertilizer costs and due to more availability of time; however the fall application of inorganic $\mathrm{N}$ fertilizers is often inferior to the spring application for increasing yields (Malhi et al. 2003) and create higher $\mathrm{N}$ losses to the environment. The inorganic $\mathrm{N}$ fertilizer shipments including producers, wholesale distributors and retail distributors in the Canadian Prairie between July 2007 and June 2008 were: ammonia $(574,000)$, urea $(1,623,000)$, urea ammonium nitrate $(616,000)$, and ammonium sulphate $(562,000)$ tonnes (CFI 2009).

Nitrous oxide emission estimates from several experiments in Canada based on measurements in non-manure cropping systems $(n=383)$ were linearly fitted to $\mathrm{N}$ application rate $\left(\mathrm{N}_{\mathrm{app}} ; \mathrm{kg} \mathrm{N} \mathrm{ha}^{-1}\right)$ which resulted in the following equation:

$\mathrm{N}_{2} \mathrm{O}-\mathrm{N}$ emission $\left(\mathrm{kg} \mathrm{ha}^{-1}\right)=0.405+0.0118\left(\mathrm{~N}_{\text {app }}\right)$

The estimation was further fine-tuned by excluding short period observations and the fertilizer induced emission was increased to:

$\mathrm{N}_{2} \mathrm{O}-\mathrm{N}$ emission $\left(\mathrm{kg} \mathrm{ha}^{-1}\right)=0.245+0.0136\left(\mathrm{~N}_{\text {app }}\right)$ which implies an emission rate of $0.245 \mathrm{~kg} \mathrm{~N}_{2} \mathrm{O}-\mathrm{N} \mathrm{ha}^{-1}$ year $^{-1}$ from non fertilized soil (Helgason et al. 2005). Rochette et al. (2008) used $0.008 \mathrm{~kg} \mathrm{~N}_{2} \mathrm{O}-\mathrm{N} \mathrm{kg}^{-1} \mathrm{~N}_{\text {app }}$ as regional emission factor (EFreg) for the Black soil zone since the semi-arid conditions of the Prairie region resulted in very small $\mathrm{N}_{2} \mathrm{O}$ emissions vs. Fertilizer $\mathrm{N}$ slopes, which was not statistically significant from 0 . The EFreg was obtained from the difference the mean $\mathrm{N}_{2} \mathrm{O}$ emissions at fertilizer rates of $80 \mathrm{~kg} \mathrm{~N} \mathrm{ha}^{-1}$.

Experiments on the effects of sources of $\mathrm{N}$ fertilizers on $\mathrm{N}_{2} \mathrm{O}-\mathrm{N}$ are summarized in Table 2. The $\mathrm{N}_{2} \mathrm{O}-\mathrm{N}$ emission for some fertilizers, from data-aggregation of global studies showed wide range when expressed as percentage of $\mathrm{N}$ applied: $0 \%$ to $30.5 \%$ for ammonium nitrate, $0.05 \%$ to $19.6 \%$ for anhydrous ammonia, $0.01 \%$ to $46.4 \%$ for urea and $0.08 \%$ to $0.18 \%$ for ammonium sulphate (Snyder et al. 2007). The wide ranges could be as a result of variations in biophysical settings and experimental methods. However, in another study Tenuta and Beauchamp (2003) showed a decreasing trend of $\mathrm{N}_{2} \mathrm{O}$ emissions, expressed as percentage of $\mathrm{N}$ added on Canadian soils: urea $(0.25 \%)>$ ammonium sulphate $(0.18 \%)>$ ammonium nitrate $(0.08 \%)$. In addition, the authors observed that the highest emissions from urea and ammonium phosphate were under aerobic and anaerobic soil conditions, respectively. The highest $\mathrm{N}_{2} \mathrm{O}$ emission for ammonium phosphate under anaerobic condition was suspected due to alleviating of phosphorus limitation to denitrifiers. Walters (2005) had a different classification of the decreasing rank of $\mathrm{N}$ fertilizers expressed as percentage of $\mathrm{N}$ added as: anhydrous ammonia $(1.63 \%)>$ ammonium nitrate $(0.40 \%)>$ ammonium sulphate $(0.15 \%)>$ urea $(0.11 \%)$ and nitrate $(0.05 \%)$.

The GHG emission can vary with other nutrient application variables (i.e. timing, placement of application). The combination of fertilizer sources and the variables are key issues that contribute to the improvement of $\mathrm{N}$ use efficiency and reduction of GHG emissions. Tenuta and Beauchamp (2003) indicated the importance of methodsrefinement to predict $\mathrm{N}_{2} \mathrm{O}$ emissions based on $\mathrm{N}$ fertilizer source use and moisture. Such a refinement may reduce the uncertainties in inventories of national estimates of $\mathrm{N}_{2} \mathrm{O}$ emissions from agriculture. 
Table 2 Summary - effect of nitrogen fertilizer on $\mathrm{N}_{2} \mathrm{O}$ emission

\begin{tabular}{|c|c|c|c|}
\hline Source & Emission $\left(\mathrm{N}_{2} \mathrm{O}-\mathrm{N}\right) \%$ of applied $\mathrm{N}$ & References & Benefits \\
\hline Urea & $\begin{array}{l}0.01-46.4 \% \\
0.25 \% \\
0.11 \%\end{array}$ & $\begin{array}{l}\text { (Snyder et al. 2007), } \\
\text { (Tenuta and Beauchamp 2003), } \\
\text { (Walters 2005) }\end{array}$ & $\begin{array}{l}\text { Source of fertilizer affects the GHG emissions. } \\
\text { Evaluation of the relative effects of source of } \\
\text { fertilizers on crop productivity and net GHG } \\
\text { emission could be important. }\end{array}$ \\
\hline Ammonium nitrate & $\begin{array}{l}0-30.5 \% \\
0.08 \% \\
0.40 \%\end{array}$ & $\begin{array}{l}\text { (Snyder et al. 2007), } \\
\text { (Tenuta and Beauchamp 2003), } \\
\text { (Walters 2005) }\end{array}$ & \\
\hline Anhydrous ammonia & $\begin{array}{l}0.05-19.6 \% \\
1.63 \%\end{array}$ & $\begin{array}{l}\text { (Snyder et al. 2007), } \\
\text { (Tenuta and Beauchamp 2003) }\end{array}$ & \\
\hline Ammonium sulphate & $\begin{array}{l}0.03-0.18 \mathrm{~kg} \mathrm{ha}^{-1} \\
0.18 \% \\
0.15 \%\end{array}$ & $\begin{array}{l}\text { (Snyder et al. 2007), } \\
\text { (Tenuta and Beauchamp 2003), } \\
\text { (Walters 2005) }\end{array}$ & \\
\hline $\begin{array}{l}\text { Potassium nitrate } \\
\text { Nitrate }\end{array}$ & $\begin{array}{l}0.02 \% \\
0.05 \%\end{array}$ & $\begin{array}{l}\text { (Bembenek et al. 2006) } \\
\text { (Walters 2005) }\end{array}$ & \\
\hline $\begin{array}{l}\text { Monoammonium } \\
\text { phosphate }\end{array}$ & $1.23 \%$ & (Tenuta and Beauchamp 2003) & \\
\hline
\end{tabular}

Measurement conditions: greenhouse experiment for 8 weeks (Bembenek et al. 2006), data aggregate (Snyder et al. 2007), laboratory incubation for 21 days (Tenuta and Beauchamp 2003), and laboratory experiment for 42 days (Walters 2005).

$2.2 \mathrm{~N}$ fertilizers formulations-nitrification/urease inhibitors and enhanced efficiency fertilizers

Nitrification inhibitors (i.e. dicyandiamide (DCD), nitropyrin, 3,4 dimethyl pyrazole phosphate) (Zaman et al. 2008) and urease inhibitor such as ( $n$-butyl)-thiophosphoric triamide (NBPT) can reduce $\mathrm{N}$ emissions from soils. Nitrification inhibitors slow the activity of Nitrosomonas, the genus of nitrifying bacteria responsible for the oxidation of $\mathrm{NH}_{4}{ }^{+}$to $\mathrm{NO}_{2}^{-}$, thereby can reduce $\mathrm{NO}_{3}{ }^{-}$leaching and $\mathrm{N}_{2} \mathrm{O}$ emissions (Zaman et al. 2008). Urease inhibitors slow down the conversion of urea into ammonia and $\mathrm{CO}_{2}$ $\left(\left(\mathrm{NH}_{2}\right)_{2} \mathrm{CO}+\mathrm{H}_{2} \mathrm{O} \rightarrow 2 \mathrm{NH}_{3}+\mathrm{CO}_{2}\right)$. Agrotain is a mixed solvent additive containing NBPT used as urease inhibitor with urea or UAN and DCD is most widely used as nitrification inhibitor. In addition, fertilizers can be produced coated by polymers for similar purposes which are called slowly released fertilizers. The Environmentally Smart Nitrogen (ESN) refers to one of the most commonly used polymer-coated urea fertilizers.

In the Canadian Prairie, fall applied $\mathrm{N}$ are subject to timecourse dynamics of temperature and emissions. The inhibitors and coated $\mathrm{N}$ fertilizers could be important by providing farmers wider time-spectrum for $\mathrm{N}$ application at early fall with minimum risk of volatilization until the soil freezes. Similarly, such fertilizers when applied in spring could be important in delaying the release of $\mathrm{N}$ till the crop demand is high. However, the effect may be affected by soil temperature and soil type. Tiessen et al. (2006) concluded, from experiment in Red River Valley, that fall banded urea containing both DCD and NBPT slowed nitrification by $50 \%$ and increased retention of fertilizer $\mathrm{N}$ as $\mathrm{NH}_{4}{ }^{+}$in the fall. Thus, suggested even if fall applied urea without inhibitors is banded, addition of inhibitors could improve the $\mathrm{N}$ recovery and retention further. Similarly, fall applied ESN under high soil moisture conditions can produce the same yield while reducing $\mathrm{N}_{2} \mathrm{O}$ emission. The cost of ESN is estimated to be $10 \%$ higher than urea (Keith, R. Pers. Comm., OMAF, ON). The effectiveness of inhibitors could depend on biophysical factors such as soil texture, temperature and/or organic content. The temporal effectiveness of inhibitors in relation to soil aeration, soil bulk density and oxygen concentration on reduction of GHG emissions needs further research.

\subsection{Rate, placement and timing options}

Several studies agree that the amount of $\mathrm{N}$ lost through $\mathrm{N}_{2} \mathrm{O}$ increases with increasing level of fertilizer applications (Malhi and Lemke 2007; Dobbie and Smith 2003; Stehfest and Bouwman 2006). The three important factors that can affect the $\mathrm{N}$ use efficiency and GHG emissions are rate, spatial placement and timing.

Statistics Canada (2004) showed that only $22 \%$ of the farms in the Canadian Prairie test their soil at least once a year and 34\% less than once a year, and the rest (44\%) had not tested their soils for a few years. It is commonly known that the $\mathrm{N}$ status varies even within a field; however most producers are not differentiating the nutrient status spatially. This could lead to gross mismatch of requirement to the blanket applications on particular spots across the field. Therefore, to avoid unnecessary doses, to reduce the likelihood of $\mathrm{N}_{2} \mathrm{O}$ emissions and to optimize the delivery of nutrient to the plant roots, site-specific application could be more judicious management option. 
The average amount of $\mathrm{N}_{2} \mathrm{O}$ emission, in an 8-year field study in Saskatchewan from side banding of urea (at application rates range of 40 to $120 \mathrm{~kg} \mathrm{~N} \mathrm{ha}^{-1}$ ), was quantified to be $580 \mathrm{~g} \mathrm{~N} \mathrm{ha}^{-1}$, while in the control it was $155 \mathrm{~g} \mathrm{~N} \mathrm{ha}^{-1}$ (Malhi and Lemke 2007). Application of $\mathrm{N}$ increased crop biomass (i.e. barley, wheat and canola) by $40 \%$ approximately and enhanced root biomass (up to $45 \mathrm{~cm}$ soil depth) by $32 \%$.

$\mathrm{N}$ fertilizers can be applied in various placement methods. The major groups are banding and broadcasting. There are several methods of banding (i.e. drill with the seed, side banding, mid-row banding, sub-surface banding into the soil prior to seeding, surface banding and nesting). Broadcasting can be performed either broadcast without incorporation or broadcast with incorporation into soil. According to Lefebvre et al. (2005), the percentage share of methods of application for the year 2001, in the Canadian Prairie, were $11 \%$ (injected or knife), $1 \%$ (post plant top or side dressing), 46\% (applied with the seed), 20\% (banding), $21 \%$ (broadcast) and $1 \%$ (others). Only $10 \%$ of the farmers adopted a nutrient management plan.

Timing is a crucial issue of $\mathrm{N}$ management in agricultural fields. Fall application can be further divided into three periods namely early, mid and late. Spring application can be divided into early and late spring. In some cases, it could be applied both in the fall and spring by splitting the total recommended amount into partial doses. Fall application usually gives similar yield to that of the spring application, but $\mathrm{N}$ loses in fall application are higher. In the Canadian Prairie, fall applied $\mathrm{N}$ are subjected to timecourse interaction of temperature and volatilization. To slow the $\mathrm{N}$ loss through nitrification before freezing and thus increase $\mathrm{N}$ use efficiency in spring, Tiessen et al. (2006) suggested delaying application of fall banded $\mathrm{N}$ until mid-October.

The efficiency of fertilizer $\mathrm{N}$ use could be optimized by proper selection of rate, source of the fertilizer, timing and type of plant. For instance, drilling with the seed is related to high risk of seed damage when uncoated urea is used and the application of urease inhibitors could reduce seed damage. Malhi et al. (2003) reported that polymer-coated urea was the most effective followed by Agrotain in comparison to uncoated urea when seed-row placed on wheat and canola. Malhi et al. (2008) concluded that there were few differences in the agronomic performance of flax from urea vs. anhydrous ammonia and side-band vs. midrow band. They suggested that broadcast urea can be less effective than side-banded urea, and fall banded $\mathrm{N}$ can be inferior to spring-banded $\mathrm{N}$.

Nitrogen fertilizers are highly dynamic in soil and, particularly, frequent diagnosis of soil $\mathrm{N}$ status is required. Duke (2006) suggested that testing the nitrate status of the soil during the early growing season of corn, when the plant requirement is high, could reduce the $\mathrm{N}$ application rate by $15 \%$, thus reducing $\mathrm{N}_{2} \mathrm{O}$ emission. This is because whenever the applications of $\mathrm{N}$ fertilizers exceed the ecosystem $\mathrm{N}$ uptake capacity (i.e. which can be estimated from pre-planting measurements of residual $\mathrm{N}$ and net input-output balances) it would largely increase the $\mathrm{NO}_{3}{ }^{-}$ and $\mathrm{N}_{2} \mathrm{O}$ emission (Grant et al. 2006).

Field emissions of $\mathrm{N}_{2} \mathrm{O}$ and $\mathrm{CO}_{2}$ are related to thaws. It was estimated annually that $70 \%$ of the $\mathrm{N}_{2} \mathrm{O}$ and $10-25 \%$ of the $\mathrm{C}$ budget are emitted during the spring thaw. The emissions during winter thaw were also considerable. The relationship between the $\mathrm{N}_{2} \mathrm{O}$ fluxes and soil temperature was especially greatest at the surface (air and soil temperature at $5 \mathrm{~cm}$ ) and decreases with soil depth (Furon et al. 2008). This finding has an important implication to fine tune $\mathrm{N}$ placement methods. Wagner-Riddle et al. (2008a) found that ${ }^{15} \mathrm{NO}_{3}{ }^{-}$applied to the soil surface layer $\left(0\right.$ to $5 \mathrm{~cm}$ ) resulted in $\mathrm{N}_{2} \mathrm{O}$ fluxes at spring thaw that were 1.5 to 5 times higher than when applied at depths of 12 to $17 \mathrm{~cm}$.

The potential to reduce GHG emissions by optimization of nutrient management could be enhanced through proper selection of sources, applying the right rate, and improvement in placement techniques as well as choosing the appropriate timing of inorganic $\mathrm{N}$ fertilizers. The presently used $1 \%$ (IPCC 2006) of $\mathrm{N}_{2} \mathrm{O}-\mathrm{N}$ emission from the applied inorganic $\mathrm{N}$ fertilizer is general and it needs to be refined for each of the fertilizer sources, placement and timing options. Most likely, the GHG emissions could also be affected by the interaction matrix of the nutrient management options mentioned above.

\section{Livestock}

The total number of cattle in the Canadian Prairie in 2008 was 10.9 million and pigs 5.22 million at any given time (Statistics Canada 2009). Livestock production related GHG emissions include $\mathrm{CH}_{4}$ directly emitted from domestic animals (of which about $90 \%$ are from enteric fermentation of ruminants), $\mathrm{CH}_{4}$ and $\mathrm{N}_{2} \mathrm{O}$ from manure and grazed lands, and $\mathrm{N}_{2} \mathrm{O}$ from soils after application of manure (Fig. 2). The BMP related to livestock are ranked in Table 3. Feeding strategies, manure storage and anaerobic digestion are given the highest priority. The benefit or otherwise of composting to reduce GHG needs further studies. The most important mitigation strategies related to livestock production are discussed below.

\subsection{Enteric fermentation}

Enteric $\mathrm{CH}_{4}$ production arises principally from microbial fermentation of hydrolysed dietary carbohydrates such as 


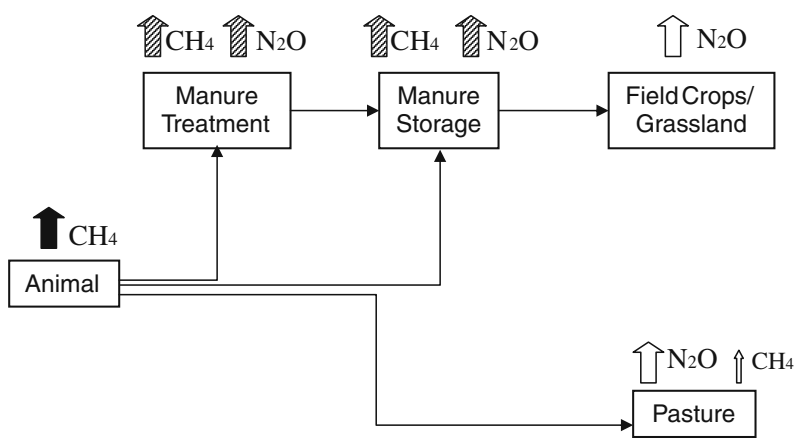

Source of emissions:

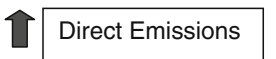

Manure Management

Soils

Fig. 2 Flow of manure from animal to fields and sources of $\mathrm{CH}_{4}$ and $\mathrm{N}_{2} \mathrm{O}$ emission associated with components of animal production. Methane from pasture is negligible. Adapted from Kebreab et al. (2006)

cellulose, hemicelluloses, pectin and starch and the amount of $\mathrm{CH}_{4}$ emission from animals depends on type and amount of feed ingested. The loss of $\mathrm{CH}_{4}$ from animals is not only an environmental concern. Methane emissions represent an energetic loss that impacts on profitability of livestock production through reduced feed conversion efficiency (Moe and Tyrrell 1979; France and Kebreab 2008). The amount of $\mathrm{CH}_{4}$ produced by an animal is influenced by many factors including dietary factors such as type of carbohydrate in the diet, level of feed intake, and degree of saturation of lipids in the diet (Kebreab et al. 2006). Mitigation strategies to reduce enteric $\mathrm{CH}_{4}$ emissions from cattle has been extensively reviewed by Boadi et al. (2004a) and updated by Kebreab et al. (2006). Therefore, mitigation strategies will be discussed here briefly and will focus on recent studies and those that are relevant to the Canadian Prairie's animal production systems.

\subsubsection{Feeding management}

Several practices have been conducted as a BMP in the Canadian Prairie to improve the feeding management of livestock. These include: improved management of perennial forage stands, stockpiling perennials, crop aftermath, and annuals for fall grazing, swath grazing and bale grazing (Havens and Lastiwka 2008). Wittenberg and Boadi (2001) suggested promotion of high quality forages in ruminant feeding and grazing systems to reduce GHG emissions. The management of grazing, pasture or feedlot has an impact on GHG emissions. A comparative study was conducted by McCaughey et al. (1997) on stocking rate and rotational or continuous grazing of crossbred yearling steers which grazed $60 \%$ alfalfa, $40 \%$ grass pastures and managed by rotational or continuous grazing at each of heavy and lightly stocked rates. The authors reported that continuously grazed,

Table 3 Beneficial management practices (BMP) related to livestock management, recommended for the province of Manitoba to reduce the GHG emission and increase the environmental stewardship (modified after Eco-ressources Consultants 2009)

\begin{tabular}{|c|c|c|c|c|}
\hline BMP & Emission reduction potential & Side effects/Co-benefits/barriers & Knowledge gaps & Recommendations \\
\hline Feeding strategies ${ }^{\mathrm{a}}$ & $\begin{array}{l}\text { Efficiency affected by several } \\
\text { factors; depending on strategy } \\
\text { or up to } 50 \% \text { reduction } \\
\text { compared with mature pasture }\end{array}$ & $\begin{array}{l}\text { Increase to producers of } \\
\$ 57-\$ 282 \mathrm{t}^{-1} \text { of GHGs } \\
\text { emitted has been projections } \\
\text { depend on feeding strategy }\end{array}$ & $\begin{array}{l}\text { Increasing efficiency of } \\
\text { feed conversion }\end{array}$ & $\begin{array}{l}\text { Highly } \\
\text { recommended }\end{array}$ \\
\hline Anaerobic digestion $^{\mathrm{b}}$ & $\begin{array}{l}\text { Depend on several factors; } \\
20-40 \% \text { reductions in } \mathrm{N}_{2} \mathrm{O} \\
\text { emissions; mitigates } \\
0.42-0.5 \mathrm{t} \mathrm{CO}_{2} \mathrm{e} \mathrm{m}^{-3} \text { of manure }\end{array}$ & - & $\begin{array}{l}\text { Methane captured can } \\
\text { offset fossil fuel use }\end{array}$ & $\begin{array}{l}\text { Highly } \\
\text { recommended }\end{array}$ \\
\hline Storage cover ${ }^{\mathrm{c}}$ & $\begin{array}{l}\text { Efficiency affected by several } \\
\text { factors; mitigates up to } \\
0.69 \mathrm{t} \mathrm{CO}_{2} \mathrm{e} \mathrm{m}^{-3} \text { of manure }\end{array}$ & $\begin{array}{l}\text { Increase to producers of } \$ 4 \mathrm{t}^{-1} \\
\text { of GHGs emitted }\end{array}$ & $\begin{array}{l}\text { Leakage from cover; } \\
\text { incomplete combustion }\end{array}$ & $\begin{array}{l}\text { Highly } \\
\text { recommended }\end{array}$ \\
\hline $\begin{array}{l}\text { Improved handling/ } \\
\text { barn clean }^{\mathrm{d}}\end{array}$ & $\begin{array}{l}\text { Projected reduction on prairie up } \\
\text { to } 26000 \mathrm{t} ; 20-40 \% \mathrm{~N}_{2} \mathrm{O} \\
\text { reduction by improving manure } \\
\text { management }\end{array}$ & $\begin{array}{l}\text { Removing fall application of } \\
\text { manure estimated to cost } \\
\$ 237 \text { per tonnes of GHG emitted }\end{array}$ & $\begin{array}{l}\text { May result in higher } \mathrm{N} \\
\text { in manure }\end{array}$ & Recommended \\
\hline Composting $^{\mathrm{e}}$ & $\begin{array}{l}\text { Unproven; emits } 0.24-0.40 \mathrm{t} \\
\mathrm{CO}_{2} \mathrm{e} \mathrm{t}^{-1} \text { of manure }\end{array}$ & - & More research needed & Not recommended \\
\hline
\end{tabular}

\footnotetext{
${ }^{a}$ Kulshreshtha et al. (2001); Wittenberg and Boadi (2001); Philippe et al. (2007); Kulshreshtha et al. (2001); Kebreab et al. (2006)

${ }^{\mathrm{b}}$ Duke (2006)

${ }^{\mathrm{c}}$ Duke (2006); Kulshreshtha et al. (2001); Clemens et al. (2006); Amon et al. (2007)

${ }^{d}$ Kulshreshtha et al. (2001), Duke (2006), Philippe et al. (2007); Gregorich et al. (2005); Kebreab et al. (2006); Duke (2006), Amon et al. (2007)

${ }^{\mathrm{e}}$ Hao et al. (2004); Pattey et al. (2005)
} 
heavily stocked pasture resulted in lowest $\mathrm{CH}_{4}$ emissions 242.2 $\mathrm{L} \mathrm{day}^{-1}$ per animal, and the highest emissions per animal were $306.7 \mathrm{~L} \mathrm{day}^{-1}$ from continuously grazed lightly stocked pasture. However, when $\mathrm{CH}_{4}$ production measurements were compared on per kilogram of body weight gained basis, no differences were found between the grazing treatments with the average of $0.69 \pm 0.06 \mathrm{~L} \mathrm{~kg}$ $\mathrm{BW}^{-1}$ day $^{-1}$. Bannink et al. (2010) compared various types of grass management using a mechanistic model and reported that the lowest $\mathrm{CH}_{4}$ emission was established for early cut, high fertilized grass silage and high fertilized grass herbage. The highest emission was found for late cut, low-fertilized grass silage.

Harper et al. (1999) observed that cattle grazed on lowquality, high-fibre pasture produced higher $\mathrm{CH}_{4}$ production (about four times) compared to cattle fed high-grain diets. This corresponds to the conversion of 7.7 to $8.4 \%$ of gross energy (GE) into $\mathrm{CH}_{4}$ for low-quality-fibre diet and only 1.9 to $2.2 \%$ for high-grain diets. The conversion rates are similar to those indicated by Kebreab et al. (2008) but higher (for the former) and lower (for the latter, respectively) in comparison to IPCC estimates. Ominski et al. (2006) also found that $\mathrm{CH}_{4}$ emissions were influenced by pasture quality and availability, as highest emissions were observed when the quality was low and dry matter availability was limited (11\% of GE). The addition of grains, such as corn, barley or wheat, to the diet could reduce $\mathrm{CH}_{4}$ emissions per unit of animal product.

However, an imbalance in the nutrient content of the feed consumed, such as shortfall in the amount of protein or mineral, can increase the amount of $\mathrm{CH}_{4}$ produced. Cattle fed in a feedlot usually emit less $\mathrm{CH}_{4}$ than grazing cattle as a result of increased grain consumption and the ration is formulated to meet the animal's nutrient requirement (Kebreab et al. 2006). Harper et al. (1999) reported $\mathrm{CH}_{4}$ emission of $0.23 \mathrm{~kg}$ (animal) $)^{-1} \mathrm{day}^{-1}$ for cattle grazing on pasture and $0.07 \mathrm{~kg}$ (animal) ${ }^{-1}$ day $^{-1}$ for the same cattle type fed a highly digestible, high-grain diet.

\subsubsection{Forage:grain ratio and restricted feed intake}

Most of the literature show that feeding diets with low forage:grain ratio is an effective means of reducing $\mathrm{CH}_{4}$ output per unit live weight gain and improves feed conversion efficiency. For example, Boadi et al. (2004b) reported a $42 \%$ lower $\mathrm{CH}_{4}$ production from steers fed low forage:grain ratio compared to those fed high forage:grain ratio and overall $\mathrm{CH}_{4}$ production ranged from 0.9 to $6.9 \%$ and from 0.7 to $4.9 \%$ GE intake, respectively. Kirkpatrick et al. (1997) reported that restricting feed intake significantly lowered $\mathrm{CH}_{4}$ production compared to ad libitum fed beef cattle. The authors reported $2.5 \%$ of GE lower $\mathrm{CH}_{4}$ emissions in cattle on restricted diet.

\subsubsection{Nutritional manipulations}

Addition of fats, particularly medium chain fatty acids to animal feed have been shown to reduce enteric $\mathrm{CH}_{4}$ production. This is most likely due to reduced total $\mathrm{H}_{2}$ supply in the rumen through a reduction of the total amount of rumen fermented organic matter following defaunation, a shift towards propionate production and provision of an alternative $\mathrm{H}_{2}$ sink through bio-hydrogenation. In a recent Canadian study, Odongo et al. (2007c) showed that a 5\% inclusion of myristic acid (medium chain fatty acid) resulted in $36 \%$ reduction (from 608.2 to $390.6 \pm 56.46 \mathrm{~L} \mathrm{day}^{-1}$ ) in $\mathrm{CH}_{4}$ production, further confirming a study by McGinn et al. (2004) who reported a $21 \%$ reduction by adding sunflower oil to the diet. A concern regarding addition of fat into diet is the alteration of fatty acid profile in milk fat. However, Odongo et al. (2007c) showed that addition of myristic acid did not alter the conjugated linoleic acid and trans-18:1 fatty acid profile in milk. Using North American diets as an input, Kebreab et al. (2008) calculated $\mathrm{CH}_{4}$ emission from diets containing $4.5 \%$ diet and reported a reduction of emissions by at least $1 \%$ of GE intake.

Many studies have demonstrated that types of carbohydrates consumed affect $\mathrm{CH}_{4}$ production. Hindrichsen et al. (2004) reported that supplements with higher non-cellular polysaccharides (such as guar gum and starch) favoured propionateforming microbes and therefore diverted $\mathrm{H}_{2}$ away from methanogens. Simple sugars promote acetate and butyrate formation at the expense of propionate, which provides $\mathrm{H}_{2}$ for methanogens and therefore increases $\mathrm{CH}_{4}$ production. Mills et al. (2001) showed that diets with starch considerably lowered $\mathrm{CH}_{4}$ production compared to diets with sugars.

\subsubsection{Growth promoters, ionophores, and organic acids}

Natural growth promoters such as testosterone, estradiol, and progesterone, and synthetic ones such as melengestrol acetate, trenbolone acetate, and zeranol are used in livestock production. Growth promoters could increase feed use efficiency, reduce land requirements and reduce GHG per unit of product. Grain feeding combined with growth promoters resulted in about $40 \%$ reduction in GHG per pound of beef compared to grass feeding (excluding $\mathrm{N}_{2} \mathrm{O}$ ), with the growth promoters accounting for $25 \%$ of the reduction observed (Avery and Avery 2008). In a long-term experiment in Ontario, Odongo et al. (2007a) observed a reduction of $\mathrm{CH}_{4}$ production using monensin by $7 \%$ (when expressed in $\mathrm{g} \mathrm{day}^{-1}$ ) and by $9 \%$ (when expressed as $\mathrm{g}(\mathrm{kg}$ body weight $)^{-1}$ ) in lactating dairy cows. This is in agreement with an experiment in Alberta by McGinn et al. (2004) who reported a $9 \%$ reduction of $\mathrm{CH}_{4}$ emission per $\mathrm{kg}$ of dry matter intake due to the use of monensin. In the former study by Odongo et al. (2007a), the application 
of monensin reduced milk fat percentage by $9 \%$ and milk protein percentage by $4 \%$. Odongo et al. (2007b) reported that monensin was at least partly effective in inhibiting the bio-hydrogenation of unsaturated fatty acids in the rumen and consequently increased the percentage of $n-6$ and $n-3$ polyunsaturated fatty acid and conjugate linoleic acid in milk, thus enhancing the nutritional properties of milk with regard to human health. The effect of organic acids (such as malate and fumarate) in reducing $\mathrm{CH}_{4}$ output is not conclusive. In their review, Castillo et al. (2004) from in vitro studies concluded that inclusion of organic acids has the potential to reduce methanogenesis but McGinn et al. (2004) did not observe significant effects of adding yeast and fumaric acid on $\mathrm{CH}_{4}$ emissions.

\subsubsection{Feed processing}

Methane emissions from steam flaked vs. cracked corn component-fed (which includes corn silage, mixed hay, and corn) cows on a commercial dairy farm in Ontario were compared. The cracked corn ration reduced $\mathrm{CH}_{4}$ emissions by $14 \%$ (616 vs. $704 \mathrm{~L} \mathrm{CH}_{4}$ day $^{-1}$, cracked corn vs. steam flaked, respectively). These results suggest that enteric $\mathrm{CH}_{4}$ emissions from dairy cows can be reduced significantly using simple dietary manipulation strategies and shifting the site of digestion from the rumen to the small intestine (Odongo et al. 2006).

\subsubsection{Genetic selection}

A few measured experiments in Alberta have shown that beef cattle differ in their residual feed intake (RFI, the difference between the intake of metabolisable energy (ME) intake and ME required for maintenance and gain; e.g. Okine et al. 2003; Nkrumah et al. 2006). The authors found that cattle with low RFI reduced $\mathrm{CH}_{4}$ production by $28 \%$ compared to those with high RFI and suggested that traits which are related to individual differences in microbial population in the rumen could be heritable. Similarly, Pinares-Patiño et al. (2003) from a controlled grazing experiment observed most of the differences associated with $\mathrm{CH}_{4}$ production were intrinsic animal differences which could be heritable. It is possible that the effect of genetic selection may be related to variation in digestion instead of variation in ME utilization by the animal.

\subsection{Manure}

Manure is a complex matrix consisting of a phenomenal concentration of micro-organisms (comprising of bacteria, protozoa and fungi). In Canada, manure is stored over several months; with an estimated $14 \%$ of livestock operations using liquid storage, $69 \%$ using solid storage and $24 \%$ keep their animals on pasture year-round or spreading manure daily (Statistics Canada 2003). Next to enteric fermentation, manure storage is one of the most significant source of $\mathrm{CH}_{4}$. Gas emissions from animal manures vary with type of animal, diet, management of manure and climatic conditions (NRC 2003). Due to these factors, and the paucity of measurements in Canadian conditions, livestock-related manure emission estimates of these gases are very uncertain (Janzen et al. 1998). In one of the few studies available on manure contribution to GHG emission, the effect of diet formulation was shown to influence the $\mathrm{C}: \mathrm{N}$ ratio of excreted manure, which in turn, has the potential to influence the extent of $\mathrm{CH}_{4}$ released from stored manure. For example, Rejis (2007) showed that feeding diets high in fibre and low in protein results in slurry with relatively high $\mathrm{C}: \mathrm{N}$ ratio and low inorganic $\mathrm{N}$ : total $\mathrm{N}$ which can give microbes substrates that can be converted to $\mathrm{CH}_{4}$ during storage. In fact, Huang et al. (2010) predicted high $\mathrm{C}$ substrates in manure to yield high amount of $\mathrm{CH}_{4}$ production during anaerobic storage. Cattle consuming high forage diets produce manure with a higher content of partially digested cell wall material, which escaped microbial degradation and subsequent release of $\mathrm{C}$ as compared to cattle consuming higher grain (Boadi et al. 2002).

\subsection{Greenhouse gases emissions from manure applied soil}

Beef, swine and poultry are the major livestock groups in the Canadian Prairie and manure application is one of the most important nutrient management strategies. However, the main concern of manure application is associated with GHG emissions (Jarecki et al. 2008). On a category basis, domestic animals are estimated to contribute directly $32 \%$ (19 Mt), manure management 17\% (10 Mt), and soils (partly manure amended) $50 \%\left(30 \mathrm{Mt} \mathrm{CO}_{2} \mathrm{e}\right.$ ) of Canadian agricultural emissions. Given the importance of livestockrelated GHG contribution, there is a potential for BMP that take animal production, manure management and field application of manure into consideration to mitigate Canadian agricultural emissions in general and western Canada specifically (Kebreab et al. 2006).

Increasing nutrient utilization of livestock from feed by incorporating enzymes such as phytase (Jongbloed et al. 1992) has been a strategy to reduce nutrient load in the excreta. This modifies the chemical composition of manure (Velthof et al. 2003) and reduced the mineral $\mathrm{N}$ $\left(\mathrm{NH}_{4}-\mathrm{N}\right.$ and $\left.\mathrm{NO}_{3}-\mathrm{N}\right)$ by $6.3-9.8 \%$ when expressed as a percentage of the Total $\mathrm{N}$ of manure (Pillai et al. 2009) therefore, GHG emissions from manure applied soils. Little quantitative information on the effect of manure composition changes on GHG emissions is available mainly because of the lack of integration of the GHG 
emissions from soils with the processes at the animal level. Recently, reduced GHG emission was observed from manure of pigs fed diets supplemented with phytase on Manitoban clay soil (Yitbarek et al. 2009).

\subsection{Net greenhouse gases emissions from animal agriculture}

It has to be emphasized that decisions to reduce GHG emissions from animal agriculture need to be taken based on the net emissions after considering emissions due to feed production, feed transportation, enteric emissions, manure storage, and application to soil and calculated per unit of product produced (milk, meat etc.) and/or per unit of area occupied. Stewart et al. (2009) compared whole-farm emissions per unit of protein output of 11 management systems based, in part, on equations recommended by IPCC. The authors showed that compared to the baseline management scenario, pasturing cattle on alfalfa-grass had the largest decrease $\left(0.39\right.$ to $\left.0.66 \mathrm{Mg} \mathrm{CO}_{2} \mathrm{e}(\mathrm{Mg} \text { protein })^{-1}\right)$ in emissions for all locations. Feeding lower quality forage over winter had the greatest increase in emissions per unit protein on northern and southern Alberta, with increases 1.08 and $1.14 \mathrm{Mg} \mathrm{CO}_{2} \mathrm{e}$ ( $\mathrm{Mg}$ protein $)^{-1}$, respectively. Eliminating the fertilization of forages resulted in the largest increase $\left(2.40 \mathrm{Mg} \mathrm{CO} \mathrm{CO}_{2} \mathrm{e}(\mathrm{Mg} \text { protein })^{-1}\right)$ in emissions per unit protein on a Saskatchewan farm, while reducing the fertilizer rate by half for all crops showed the largest increase $\left(2.19 \mathrm{Mg} \mathrm{CO}_{2} \mathrm{e}(\mathrm{Mg} \text { protein })^{-1}\right)$ on a Manitoba farm. Schils et al. (2006) concluded that full accounting system could show how $\mathrm{N}$ management reduce the GHG emissions in dairy farm and agriculture as a whole. The authors calculated a reduction of the $\mathrm{N}$ surplus per kg milk with $1 \mathrm{~g} \mathrm{~N}$, through reduced fertilizer use and reduced grazing time, diminished the GHG emissions per kg milk with approximately $29 \mathrm{~g} \mathrm{CO}_{2} \mathrm{e}$.

\section{Cropping systems}

Cropping systems refer to the management of farm in space and time. Because, it allows greater carbon sequestration, intensification of the cropping system is one of the strategies used to mitigate climate change. In the Canadian Prairie, it may include: incorporation of pulses such as field peas (Pisum sativum), dry beans (Phaseolus vulgaris), soybeans (Glycine max), faba beans (Vicia faba or Faba vulgaris), lentil (Lens culinaris Medik.); and rotation of forages such as clover (Trifolium spp.), alfalfa (Medicago sativa), sweet clover (Melilotus officinalis), meadow bromegrass (Bromus riparius Rehm.), timothy (Phleum pratense) and orchard grass (Dactylis glomerata); use of cover crops such as, berseem clover (Trifolium alexandri- num), hairy vetch (Vicia villosa), winter wheat (Triticum aestivum), red clover (Trifolium pratense), annual alfalfa, Italian ryegrass (Lolium multiflorum) and sweet clover (Melilotus officinalis). In addition, tillage practices could also be considered as one of the cropping systems. Cropping systems provide not only opportunities in reducing $\mathrm{N}_{2} \mathrm{O}-\mathrm{N}$ but also in improving energy use efficiency and in increasing carbon sequestration.

The advantages of crop intensification on environment are related to the improvement of energy use efficiency, soil quality, soil moisture and $\mathrm{N}$ fixation. In a typical North American farm, the consumption of energy can be broken down as follows: $36 \%$ (fuel to run the machinery), $38 \%$ (production of inorganic $\mathrm{N}$ fertilizer), 10\% (transportation) and the rest for $\mathrm{P}$ and $\mathrm{K}$ fertilizers, seed, pesticide and production of farm equipment (Heichel 1980). This implies $74 \%$ of the energy budget of farms is allocated to fuel consumption by machinery and to $\mathrm{N}$ production.

Legumes are recognized for their ability to enrich $\mathrm{N}$ in a cropping system. The interest of growing legumes has been increasing with the rising price of $\mathrm{N}$ fertilizers (Bullied et al. 2002). In legume-non-legume crop sequences, the amount of $\mathrm{N}$ fertilizer that can be replaced depends on: (1) the quantity of legume returned to the soil, (2) the content of symbiotically fixated $\mathrm{N}$ in the residues, (3) the availability of $\mathrm{N}$ residue from legume to the subsequent crops and (4) the amount of residue incorporated to soil (Christopher and Lal 2007).

Experimental data in the Canadian Prairie showed, rotations containing $50 \%$ of perennial forage legumes decreased the non-renewable energy use by $85 \%$ and increased the energy use efficiency by $438 \%$. In addition, relative to cereals, pulses, and oilseed rotations, they reduce the non-renewable energy use by up to $28 \%$ and increased the energy use efficiency by up to $294 \%$. These efficiencies declined when fertilizers were applied (Hoeppner 2001). The values were obtained after converting all inputs, field operations and crop harvests into energy values using energy coefficients.

However, legumes have higher $\mathrm{N}_{2} \mathrm{O}$ and $\mathrm{CO}_{2}$ emissions compared to cereals and grasses. Some $\mathrm{N}_{2} \mathrm{O}$ may be emitted from $\mathrm{N}$ release as root exudates during the legume growth period (Rochette and Janzen 2005) but decomposition of residue following the growing season and in subsequent cropping season may be far more important (Helgason et al. 2005). Kagan (2000) showed 9.7 times higher $\mathrm{N}_{2} \mathrm{O}$ emissions during spring thaw in alfalfa and fallow than in native grass and wheat. Similarly, WagnerRiddle and Thurtell (1998) found higher $\mathrm{N}_{2} \mathrm{O}$ emissions for 2 years after incorporating an alfalfa crop, which could be due to the availability of easily degradable $\mathrm{N}$ than from grasses. In eastern Canada, the comparison of $\mathrm{N}_{2} \mathrm{O}$ emission $\left(\mathrm{kg} \mathrm{N}_{2} \mathrm{O}-\mathrm{N} \mathrm{ha}{ }^{-1}\right)$ from paired treatments of 
legume $(y)$ and non-legume $(x)$ crops with application of 0 to 5 and 0 to $190 \mathrm{~kg} \mathrm{~N} \mathrm{ha}^{-1}$ year $^{-1}$, respectively, was demonstrated using the regression equation: $y=0.370+$ $0.617 x$. The authors expected less emission in western compared to eastern Canada (Helgason et al. 2005). In general, because less fertilizer is used in legume based cropping systems, the overall GHG emissions are usually less than those in fertilized monocots (Lupwayi and Kennedy 2007).

\subsection{Inclusion of pulses}

Pulses are annual leguminous crops yielding from one to 12 grains within a pod, according to the Food and Agriculture Organization of the United Nations. The term pulse is reserved for crops harvested solely for the dry grain. The inclusion of pulses to oil and grain crops has been increasing rapidly. The area seeded to pulses in Canada over the last decade has increased by $1,300 \%$ (Pulse Research Council 2002).

The introduction of grain legumes could impact soil organisms, including both symbiotic and non-symbiotic Nfixing bacteria, pathogens, mycorrhizae and soil fauna. In 2004, it is estimated that about 171 million $\mathrm{kg} \mathrm{N}_{2}$ was fixed by field pea, lentil, and dry bean representing $7 \%$ of the total fertilizer N (2580 million $\mathrm{kg}$ ) used by Canadian Prairie farmers in that year. Legumes contribute to GHG reduction by replacing the $\mathrm{N}$ requirement of the cropping system than without the inclusion of pulses (Lupwayi and Kennedy 2007). An experiment by Matus et al. (1997) showed that, under zero tillage $\mathrm{N}$ fixations by lentils and peas increased by 10 and $31 \%$, respectively. The net annual contribution to the soil by $\mathrm{N}$ fixation from lentils and peas ranged from -143 to $26 \mathrm{~kg} \mathrm{~N} \mathrm{ha}^{-1}$ and from -32 to $96 \mathrm{~kg} \mathrm{~N} \mathrm{ha}^{-1}$, respectively. In another observation, field peas under conventional and no-till with application of $5 \mathrm{~kg} \mathrm{~N} \mathrm{ha}^{-1}$ in the Prairie showed 0.14 and 0.08 (Swift Current, SK, 1999-2004), and 1.72 and $0.94 \mathrm{~kg} \mathrm{~N}_{2} \mathrm{O}-\mathrm{N} \mathrm{ha}^{-1}$ (Three Hills, AB, 2002-2002), respectively. A summary of $\mathrm{N}_{2} \mathrm{O}-\mathrm{N}$ emissions during fall and spring thaw in southern Ontario ranged from 0.20 to $1.02 \mathrm{~N}_{2} \mathrm{O}-\mathrm{N} \mathrm{ha}{ }^{-1}$ for soybean (Rochette et al. 2008).

The quantification of GHG emission and C sequestration are strategic research topics of the Pulse Research Canada. However, few research results of GHG emission are available. The $\mathrm{N}_{2} \mathrm{O}$ emission for peas growth period in Brandon with fertilizer application on previous crop, was 0.55 to $0.75 \mathrm{~kg}$ $\mathrm{ha}^{-1}$ (under high soil disturbance) and 0.41 to $0.68 \mathrm{~kg} \mathrm{ha}^{-1}$ (under low soil disturbance) (Khakbazan et al. 2005). A summarized data by Snyder et al. (2007) showed that the net GHG emission from corn-soybean-wheat rotation to be 1140 (conventional tillage) and 140 (no-till) $\mathrm{CO}_{2} \mathrm{e} \mathrm{kg} \mathrm{ha}{ }^{-1}$ year $^{-1}$. In another experiment, the GHG emissions from corn-soybean rotation were $3,740 \mathrm{~kg} \mathrm{CO} \mathrm{C} \mathrm{ha}^{-1}$ year $^{-1}$ (Adviento-Borbe et al. 2007). In an extensive review by Rochette and Janzen (2005) acknowledged the importance of legumes as source of $\mathrm{N}_{2} \mathrm{O}-\mathrm{N}$ emissions and identified the above and below ground residue after harvest and the $\mathrm{N}$ release from root exudates during the growing seasons. The authors challenged the biological $\mathrm{N}$ fixation (BNF) process itself as a source of $\mathrm{N}_{2} \mathrm{O}-\mathrm{N}$. As a result, in the Canadian National Inventory from 1990 to 2008 the $\mathrm{N}_{2} \mathrm{O}-\mathrm{N}$ emission from BNF was not included (Environment Canada 2010). The comparison and evaluation of GHG emissions related to pulses and crop rotation systems could be a potential research area in the future.

\subsection{Rotational forage}

Any plant that can be eaten by animals is considered as forage. Forage production in the northern Great Plains of the USA and Canada (Manitoba, Saskatchewan and Alberta) involves cultivated and native pasture and hay production. Farmers and ranchers use cultivated forages to compliment native range (Entz et al. 2002). Increasing use of forage crop (Desjardins et al. 2001) and feeding of high quality forages was concluded to reduce GHG emissions (Kebreab et al. 2006). The direct environmental benefits of forage crops include reducing nitrate leaching when high rate of $\mathrm{N}$ fertilizer is applied, stabilization of production systems (Entz et al. 2001) and higher carbon sequestration (Johnson et al. 2007; Soussana et al. 2007).

In a 5-year rotational experiment, 3-years of alfalfa followed by wheat and barley under irrigation in Alberta showed the $\mathrm{N}_{2} \mathrm{O}$ emission to be twice more than from cornwheat-corn-wheat-barley system. Similarly, the $\mathrm{CO}_{2}$ emitted was 1.6 times higher in the alfalfa system. However, the inorganic soil $\mathrm{N}$ to the $60 \mathrm{~cm}$ soil depth in the alfalfa system was about $106 \mathrm{~kg} \mathrm{~N} \mathrm{ha}^{-1}$ while under the corn system it was $34.8 \mathrm{~kg} \mathrm{~N} \mathrm{ha}^{-1}$ (Ellert and Janzen 2008). Agronomic benefits of rotating forage crops with annual grain include higher grain following forage; improve soil quality and reduce the energy requirement by adding significant amount of $\mathrm{N}$ to the soil. In Alberta, the quantified cumulative emissions of $\mathrm{CO}_{2}$, $\mathrm{CH}_{4}$ and $\mathrm{N}_{2} \mathrm{O}$ from soil under irrigated cropping systems consisting alfalfa, wheat, and barley with contrasting $\mathrm{N}$ inputs (mineral and manure), depending on management practices ranged from 0.4 to $4.0 \mathrm{~kg} \mathrm{~N}_{2} \mathrm{O}-\mathrm{N} \mathrm{ha}^{-1} \mathrm{yr}^{-1}$ (Ellert and Janzen 2008) (Table 4). In another 24-year rotational study in Alberta Ross et al. (2008) compared (1) continuous annual grain system, (2) rotation (faba bean, red clover, alfalfa with manure), and (3) a continuous perennial grasslegume forage system with inputs from fertilizer $(18 \mathrm{~kg} \mathrm{~N}$ $\mathrm{ha}^{-1}$ year $^{-1}$ ) and white clover (Trifolium repens). The authors reported that $\mathrm{N}$ losses to the atmosphere were 4 for continuous annual grain, 28 for rotation and $24 \mathrm{~kg} \mathrm{~N} \mathrm{ha}^{-1}$ 
Table 4 Summary - effect of various agricultural activities on greenhouse gas emissions

\begin{tabular}{|c|c|c|c|}
\hline Activities & Emissions/sequestration & References & Benefits \\
\hline $\begin{array}{l}\text { Decrease forage:grain, } \\
\text { nutritional manipulation }\end{array}$ & $4.5 \%$ methane reduction & (Kebreab et al. 2008) & Reduce methane emission \\
\hline Rotational forage & $0.4-4 \mathrm{~kg} \mathrm{~N} \mathrm{~N}_{2} \mathrm{O}-\mathrm{N}$ & (Ellert and Janzen 2008) & $\begin{array}{l}\text { Reduce } \mathrm{N} \text { fertilizer use, } \\
\text { higher carbon sequestration }\end{array}$ \\
\hline Legume cover crop & $410 \mathrm{CO}_{2} \mathrm{e} \mathrm{kg} \mathrm{ha}^{-1}$ year $^{-1}$ & (Snyder et al. 2007) & $\begin{array}{l}\text { Reduce the } \mathrm{N} \text { fertilizer requirement, } \\
\text { and increase sequestration }\end{array}$ \\
\hline Tillage & $0.43-0.71 \mathrm{Mg} \mathrm{C}^{-1}$ year $^{-1}$ & (West and Post 2002) & $\begin{array}{l}\text { Increase carbon sequestration, } \\
\text { reduce fuel consumption }\end{array}$ \\
\hline Pasture management for cattle & $0.39-0.66 \mathrm{Mg} \mathrm{CO}_{2} \mathrm{e} \mathrm{Mg}^{-1}$ protein & (Stewart et al. 2009) & Decrease emissions \\
\hline Grazing management & $0.61-0.74 \mathrm{~kg} \mathrm{CO}_{2} \mathrm{e} \mathrm{kg}^{-1}$ live weight gain $\mathrm{ha}^{-1}$ & (Ominski et al. 2008) & $\begin{array}{l}\text { Increase animal weight gain and } \\
\text { pasture productivity }\end{array}$ \\
\hline Permanent cover & $0.62 \mathrm{Mg} \mathrm{C} \mathrm{ha}^{-1}$ year $^{-1}$ & (Grant et al. 2004) & Increase carbon sequestration \\
\hline
\end{tabular}

Measurement conditions: modelled (Kebreab et al. 2008), field experiment (Ellert and Janzen 2008), data aggregate (Snyder et al. 2007), data aggregate (West and Post 2002), field experiments (Stewart et al. 2009), field experiments (Ominski et al. 2008), simulation models (Grant et al. 2004).

year $^{-1}$ for continues perennial grass-legume forage system. Research in the optimization of the soil-crop-livestock system is needed (Entz et al. 2002).

\subsection{Cover crops}

Cover crops are low-growing species cultivated outside the main crop's growth period to provide soil cover (Khan 2002). Cover crops are primarily grown to prevent soil erosion and $\mathrm{N}$ leaching. The Canadian Prairie generally receives a low amount of rainfall each year, which dries out and makes it susceptible to wind erosion. The total area in Alberta, Saskatchewan and Manitoba is estimated to be 30 million hectares (Larney et al. 1995) and could be exposed, if cover crops are not used. Cover crops could be legumes, non-legume broadleaves or grasses.

Annual cover crops such as berseem clover with oat can reduce excess moisture during the growing season. This clover crop could also be used for enhancing spring snowmelt infiltration, deep percolation, and early warming of the soil by having warmer soils during the winter, shallow depths of frozen soil layers, and less frozen water content within the root zone. This in turn will allow earlier farm operations (Kahimba et al. 2008). In an organic experiment in 2004 and 2005 at Carman and Clearwater, MB, Canada, wheat grown with red clover as a cover crop was moderately successful compared to hairy vetch and annual ryegrass, which competed too aggressively with the wheat crop in wet growing conditions (University of Manitoba 2006).

The soil $\mathrm{N}$ contribution of some of the cover crops reported was as follows: $62 \mathrm{~kg} \mathrm{~N}^{-1}$ (red clover), 36 to $209 \mathrm{~kg} \mathrm{~N} \mathrm{ha}^{-1}$ (hairy vetch) (Christopher and Lal 2007), $125 \mathrm{~kg} \mathrm{~N} \mathrm{ha}{ }^{-1}$ (berseem clover) (Sheaffer et al. 2001). Snyder et al. (2007) showed that the net GHG emissions from corn-soybean-wheat rotation resulted in 630 (lowinput with legume cover crop) and 410 (organic with legume cover crop) $\mathrm{CO}_{2} \mathrm{e} \mathrm{kg} \mathrm{ha}{ }^{-1}$ year $^{-1}$ (Table 4).

\subsection{Tillage}

Conservation tillage and no-tillage practices could provide higher $\mathrm{C}$ sequestration (Johnson et al. 2007). West and Post (2002) found that a change from conventional tillage to notillage could sequester from 0.43 to $0.71 \mathrm{Mg} \mathrm{C} \mathrm{ha}^{-1}$ year $^{-1}$ (Table 4). In an experiment conducted in Saskatchewan by Malhi and Lemke (2007), $\mathrm{N}_{2} \mathrm{O}$ emissions were significantly lower from no-tillage (155 $\left.\mathrm{g} \mathrm{N} \mathrm{ha}^{-1}\right)$ than the conventional tillage (398 $\mathrm{g} \mathrm{N} \mathrm{ha}^{-1}$ ) treatments in the third year of the study. Rochette et al. (2008) summarized the effect of notillage on $\mathrm{N}_{2} \mathrm{O}$ emission and concluded that the net impact of the no-tillage on $\mathrm{N}_{2} \mathrm{O}$ emission to be highly dependent on local environment (i.e. climate, soil type). In addition, the lower farm operation from no-tillage practices could further improve the net GHG. Although, in long term, the $\mathrm{C}$ sequestration return diminishes, $\mathrm{CO}_{2}$ emissions are directly reduced since tillage fuel consumption is the greatest proportion of farming activity (Johnson et al. 2007).

Generally under Canadian Prairie production condition, there is limited study on the effect of cropping systems on the mitigation of GHG emissions, however, there is a wide understanding on the physical and hydrological effects of these BMP on soil condition which in turn affects composition and activity of the soil, and therefore, the extent of $\mathrm{N}_{2} \mathrm{O}$ production and emission from agricultural soils (Wagner-Riddle et al. 2007). Most researchers agree that mitigations based on cropping system require a longterm year-round observation of emissions to capture the interaction of crop management and weather (Wagner- 
Riddle et al. 2007). In dry areas adoption of no-tillage can be combined with other cropping system, which increases the $\mathrm{C}$ sequestration (Snyder et al. 2007).

\section{Pasture management}

\subsection{Permanent cover}

Conversion of annual cultivation to permanent cover of forage was conducted by the Prairie Farm Rehabilitation Administration's program known as Permanent Cover Program (PCP) in 1989 to 1991 . The potential of the PCP land to sequester carbon from a total area of 522,000 ha is estimated to be 5.4 to 5.7 million tonnes of carbon. There are 4.4 million ha of marginal land in Canada in annual cultivation. Therefore, if the area can be converted to permanent cover, then it could increase $\mathrm{C}$ sequestration by 50 million tonnes (Luiciuk et al. 2007).

Conversion of marginal land to permanent grassland has gained interest because of the large potential in improving soil quality while reducing GHG emissions from marginal land. The average soil sequestration potential in Canadian soil, using the CENTURY model, was predicted to be
$0.62 \mathrm{Mg} \mathrm{C} \mathrm{ha}^{-1}$ year $^{-1}$ (Table 4). For Canada, the average combined net GHG emission reduction when converting from cultivated land to permanent grassland was estimated to be approximately $2.55 \mathrm{MgCO}_{2} \mathrm{e} \mathrm{ha} \mathrm{hear}^{-1}$. This potential is expected to decline with permanency of the cover (Grant et al. 2004). Permanent cover is related to high $\mathrm{C}$ sequestration coefficient and the sequestration potential is estimated to be from 0.7 to $0.9 \mathrm{t} \mathrm{CO}_{2} \mathrm{ha}^{-1}$ year $^{-1}$ for 20 years (Table 5).

\subsection{Grazing management}

Ecological sustainable use of grazing can enhance the nutrient cycling and forage composition of grasslands (Thurow 2004). Grasslands have high soil organic matter content that supply nutrients, increase soil aggregation, limit soil erosion, and also increase cation exchange and water holding capacities. Thus, maintenance of soil organic matter is a key factor in the sustainability of grassland ecosystems (Table 5). In conventional grazing system, a single field is grazed. It is less efficient and it can be substituted by intensive rotational grazing. The latter consists of multiple small paddocks for purposeful rotation of livestock. It requires management of rest periods,

Table 5 Beneficial management practices (BMP) related to cropping systems, recommended for the province of Manitoba to reduce the GHG emission and increase the environmental stewardship (modified after Eco-ressources Consultants 2009)

\begin{tabular}{|c|c|c|c|c|}
\hline BMP & Emission reduction potential & Side effects/Co-benefits/barriers & Knowledge gaps & Recommendations \\
\hline Pulse rotations ${ }^{\mathrm{a}}$ & $\begin{array}{l}\text { Results can take years and varies } \\
\text { by region; Showed } 19 \% \text { reduction } \\
\text { in one of the Canadian study; GHG } \\
\text { reduction } 0.12-0.44 \mathrm{CO}_{2} \mathrm{e} \mathrm{t} \mathrm{ha}\end{array}$ & $\begin{array}{l}\text { Benefits can vary according } \\
\text { region; improved C } \\
\text { sequestration not a } \\
\text { permanent solution }\end{array}$ & $\begin{array}{l}\text { Research is needed to } \\
\text { determine the net GHG } \\
\text { emissions of the rotation } \\
\text { systems- }\end{array}$ & $\begin{array}{l}\text { Highly } \\
\text { recommended }\end{array}$ \\
\hline Forage rotations ${ }^{\mathrm{b}}$ & $\begin{array}{l}\text { Believed to have the highest potential } \\
\text { for GHG mitigation }\end{array}$ & $\begin{array}{l}\text { Improved C sequestration, soil } \\
\text { structure, soil fertility, water } \\
\text { quality, and reduces required } \\
\text { inputs; not always feasible } \\
\text { (e.g., in arid lands) and not } \\
\text { a permanent solution }\end{array}$ & $\begin{array}{l}\text { Quantitative results of the } \\
\text { rotations are not available- }\end{array}$ & $\begin{array}{l}\text { Highly } \\
\text { recommended }\end{array}$ \\
\hline Cover crops ${ }^{\mathrm{c}}$ & $\begin{array}{l}\text { Reduce the GHG by } \\
0.04-0.15 \mathrm{t} \mathrm{CO}_{2} \mathrm{e} \mathrm{ha}^{-1}\end{array}$ & $\begin{array}{l}\text { Improved C sequestration, not a } \\
\text { permanent solution; improves } \\
\text { soil quality }\end{array}$ & Untested in Canadian Prairie & Recommended \\
\hline Permanent cover ${ }^{\mathrm{d}}$ & 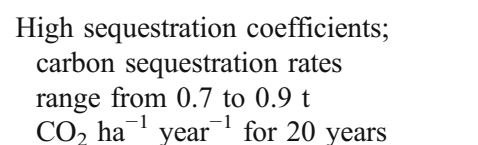 & $\begin{array}{l}\text { Important for wildlife habitat and } \\
\text { water filtration; improved water, } \\
\text { soil quality, reduced inputs and } \\
\text { disease }\end{array}$ & $\begin{array}{l}\text { More research needed on the } \\
\text { most efficient methods }\end{array}$ & $\begin{array}{l}\text { Highly } \\
\text { recommended }\end{array}$ \\
\hline Improved grazing ${ }^{\mathrm{e}}$ & $\begin{array}{l}\text { System/method dependent; } \\
\text { potential reductions range } \\
\text { from } 9 \% \text { to } 25 \%\end{array}$ & $\begin{array}{l}\text { Improves soil, water, air quality, } \\
\text { productivity, C sequestration; } \\
\text { increases costs for fencing, } \\
\text { animal management, feed, } \\
\text { milk production }\end{array}$ & $\begin{array}{l}\text { More research needed on } \\
\text { the most efficient methods }\end{array}$ & Recommended \\
\hline
\end{tabular}

\footnotetext{
${ }^{\mathrm{a}}$ Zentner et al. (2001); Lemke et al. (2007)

${ }^{\mathrm{b}}$ Smith et al. (2001); Desjardins et al. (2001); Hutchinson et al. (2007)

${ }^{\mathrm{c}}$ Lemke et al. (2007)

${ }^{\mathrm{d}}$ Smith et al. (2001); Kulshreshtha et al. (2001)

${ }^{\mathrm{e}}$ Boadi et al. (2004a, b); Kulshreshtha et al. (2001); Kebreab et al. (2006)
} 
estimation of carrying capacity and investments for fencing and water supply system (Stephenson et al. 2004).

The results of experiments conducted in Manitoba from 2003 to 2005 to identify BMP and to improve the productivity of grassland system showed that application of hog manure could improve productivity of grassland pasture without increasing net GHG emissions. The application of manure increased the $\mathrm{N}_{2} \mathrm{O}$ and $\mathrm{CO}_{2}$ emissions from 63 (control) to 196 and $250 \mathrm{~kg} \mathrm{CO}_{2} \mathrm{e} \mathrm{ha}^{-1}$ (split and fall hayed) treatments. However, the pasture productivity and additional animal weight gain was enhanced. Thus, the net $\mathrm{N}_{2} \mathrm{O}$ and $\mathrm{CH}_{4}$ emissions were unaffected by manure treatment when expressed as $\mathrm{kg} \mathrm{CO}_{2} \mathrm{e} \mathrm{kg}^{-1}$ live weight gain $\mathrm{ha}^{-1}$ over the study period (0.633 Control, 0.613 Split and 0.738 Fall kg $\mathrm{CO}_{2} \mathrm{e} \mathrm{kg}^{-1}$ live weight gain ha ${ }^{-1}$ ) (Table 5).

In addition, root growth resulted in capture of $900 \mathrm{~kg} \mathrm{C} \mathrm{ha}^{-1}$ (i.e. $3300 \mathrm{CO}_{2} \mathrm{e} \mathrm{ha}{ }^{-1}$ ), which is more than the associated $\mathrm{CH}_{4}$ and direct/indirect $\mathrm{N}_{2} \mathrm{O}$ emissions $\left(876 \mathrm{CO}_{2} \mathrm{e} \mathrm{ha}{ }^{-1}\right)($ Ominski et al. 2008). Another experiment from Alberta that investigated enhancement of dry biomass productivity concluded that three harvest can be attained from intercropping of spring and winter cereals i.e. a silage or green feed crop in the production year, re-growth for fall pasture in the production year, and spring pasture in the following year (Ford et al. 2007).

The potential and co-benefits of BMP in cropping systems and pasture management are summarized in Table 5. Pulses and forages in rotation and permanent cover are highly recommended. The effect of cover crops on GHG emissions needs to be conclusive for those conditions in the Canadian Prairie.

\section{Integration of crop-livestock systems}

Like in many parts of the Northern America, majority farmers in the Canadian Prairie have specialized either in crop or animal production systems. There is mounting evidence that this approach is neither profitable for producers nor good for environment (Tanaka et al. 2008). This has created depletions of soil nutrients in the earlier and excess accumulations in the later. With decreasing economic margins, higher energy and inorganic $\mathrm{N}$ fertilizer costs, declining soil organic matter levels, increasing concerns over the long-term sustainability of many contemporary agricultural systems, and greater regulation of agricultural practices, it is time to reconsider the potential benefits of integrating crop and livestock production (Russelle et al. 2007). In addition to the other ecological benefits, the integration of crop-livestock could provide several advantages to mitigate GHG emissions. Novak and Fiorelli (2009) identified three ways how the GHG emissions could be mitigated in mixed crop dairy systems. These are: (1) increase energy efficiency or saving of fuel (i.e. reducing distances manure and feed are transported),
(2) improve $\mathrm{N}$ use efficiency and (3) biogas production through anaerobic digestion of manure. Recently, Thelen et al. (2010) reduced the net global warming potential (GWP) by $-986 \mathrm{~g} \mathrm{CO}_{2} \mathrm{e} \mathrm{m} \mathrm{m}^{-2}$ year $^{-1}$ by integrating livestock manure with a corn-soybean bioenergy production. The main attributes for the outcome were increasing the shortterm carbon sequestration and reducing the GHG emission in the system. Long-term experimental trials to optimize the integration of crop and livestock production systems in the Canadian Prairie need to include quantification of GHG emissions to capture the mitigation opportunities that could obtain from tradeoffs.

\section{Biofuel}

The contribution of biofuel to the reduction of GHG emissions is largely controversial. Searchinger et al. (2008) estimated the GHG emission could double for corn-based ethanol and could be 50\% more for biofuel from switchgrass taking over corn-land. On the other hand, Goldemberg and Guardabassi (2009) argued that ethanol from sugarcane can reduce the GHG emissions. It is widely accepted that biofuel is important to national energy security and generation of income to rural areas, whenever higher ratios of energy prices to food prices are expected. However, the less net saving of fossil fuel, high agricultural input, competition for land (Keyzer et al. 2008) and intergovernmental and/or interprovincial taxes (Walburger et al. 2006) are among the main concerns. The availability of straw in the region is relatively high, and farmers annually prepare fields by burning straws on-site. An alternative method could be burning of the straw in oxygen limited combustion by a process known as pyrolysis. Such method could provide energy and biochar which is a promising stable carbon by-product of burned biomass that improves the chemical and physical properties of soils (Sohi et al. 2009).

\section{Boundaries of net greenhouse gases computations and limitations}

The GHG emissions from agricultural activities are diverse in source and the spatiotemporal variability is high. In addition, research approaches vary in boundary of the system, spatial scale, time of observation and methodologies. This could make the computational effort difficult.

Although there is wide agreement that process-based mathematical models play a crucial role, questions that arise on where to set the spatial boundary of quantification and how to integrate and visualize the cascade of agricultural activities on the GHG emissions are not well 
understood. Janzen et al. (2006) proposed the virtual farm concept which is boundary explicit, considering a single farm as a fundamental unit and constructed of descriptor (which characterize the farm), algorithms (which calculate emissions) and an integrator (which links the algorithms to each other and the descriptor).

Despite continuous research in the last few decades to quantify GHG emissions related to the BMP, most studies had short periods of observation and diverse methodologies. Therefore, many studies have reported a wide range of values for $\mathrm{N}_{2} \mathrm{O}$ emissions compared to the IPCC prediction of 2006 (Snyder et al. 2007). The most effective monitoring methods of emissions from agricultural activities related to soil and plants are emission chambers- and tower-based (i.e. eddy covariance) measurements. However, extrapolation of the outcome of the research to larger scale (i.e. regional, provincial) needs process-based models representing the processes at the sources of the emissions to account for the spatiotemporal variability of weather, soil condition and agricultural management. Limitations arise in creating predictive models, both from the complexity of integrating the large number of processes and lack of understanding of some of the biophysical processes (Smith et al. 2008b). Therefore, research is globally ongoing to develop valid methodology for deriving more site-specific emission factors (Grant et al. 2006).

On the other hand, GHG emissions related to animals are measured using respiration chamber or calorimeter, portable analyser, polythene tunnel, isotope dilution technique, gas tracer technique, and micrometeorological mass balance technique (Kebreab et al. 2006). The authors suggested standardization of measurement techniques in Canada to simplify the building of a national database that allow easy comparison and accurate estimations. This includes parameters that are essential for the development of predictive models in manure composition and characterization (WagnerRiddle et al. 2008b).

\section{Conclusions}

Integration of farming systems for more efficient use of natural resources per unit of agricultural product is the centre of environmental sustainability. There are several BMP in crop and animal production systems for the Canadian Prairie farms that address various environmental concerns. However, the GHG emissions of these BMP need to be evaluated. Standardization of experimental observations may improve reliability of aggregated data, sitespecific emission factors and simulation models. Specially, computation of intra-annual and trans-production systems (i.e. cropping and animal production) resource tradeoffs at farm or community levels could provide reduction of the net GHG emission of farms, thus improve further the reliability and accuracy.

Acknowledgments We thank the Manitoba Sustainable Agriculture Practices Program-R \& D Components for funding the review.

Open Access This article is distributed under the terms of the Creative Commons Attribution Noncommercial License which permits any noncommercial use, distribution, and reproduction in any medium, provided the original author(s) and source are credited.

\section{References}

Adviento-Borbe MAA, Haddix ML, Binder DL, Walters DT, Dobermann A (2007) Soil greenhouse gas fluxes and global warming potential in four high-yielding maize systems. Glob Chang Biol 13:19721988. doi:10.1111/j.1365-2486.2007.01421.x

Amon B, Kryvoruchko V, Fröhlich M, Amon T, Pöllinger A, Mösenbacher I, Hausleitner A (2007) Ammonia and greenhouse gas emissions from a straw flow system for fattening pigs: housing and manure storage. Livest Sci 112:199-207. doi:10.1016/j.livsci.2007.09.003

Avery A, Avery D (2008) The environmental safety and benefits of growth enhancing pharmaceutical technologies in beef production, Hudson Institute Center for Global Food Issues, http://www. cgi.org, Cited 15 Dec 2008

Bannink A, Smits MCJ, Kebreab E, Mills JAN, Ellis J, Klop A, France J, Dijkstra J (2010) Effects of grassland management and grass ensiling on methane emission by lactating cows. J Agric Sci 148:55-72. doi:10.1017/S0021859609990499

Bembenek A, Engel R, Dusenbury M (2006) Effect of urea nitrogen fertilizer placement on soil $\mathrm{N}_{2} \mathrm{O}$ emissions from a silt loam soil, ASA-CSSA-SSSA, Nov 12-16. International Annual Meetings, Indianapolis

Boadi DA, Wittenberg KM, McCaughey WP (2002) Effect of grain supplementation on methane production of grazing steers using sulphur $\left(\mathrm{SF}_{6}\right)$ tracer gas technique. Can J Anim Sci 82:151-157. doi:10.4141/A01-038

Boadi DA, Benchaar C, Chiquette J, Massé D (2004a) Mitigation strategies to reduce enteric methane emissions from dairy cows: update review. Can J Anim Sci 84:319-335. doi:10.4141/A03-109

Boadi DA, Wittenberg KM, Scott SL, Burton D, Buckley K, Small JA, Ominski KH (2004b) Effect of low and high forage diet on enteric and manure pack greenhouse gas emissions from a feedlot. Can J Anim Sci 84:445-453. doi:10.4141/A03-079

Bremer E, Janzen HH, Johnston AM (1994) Sensitivity of total, light fraction and mineralizable organic matter to management practices in a Lethbridge soil. Can J Soil Sci 74:131-138. doi: $10.4141 /$ cjss $94-020$

Bullied WJ, Entz MH, Smith SRJ, Bamford KC (2002) Grain yield and $\mathrm{N}$ benefits to sequential wheat and barley crops from singleyear alfalfa, berseem and red clover, chickling vetch and lentil. Can J Plant Sci 82:53-65. doi:10.4141/P01-044

Castillo C, Benedito JL, Mendez J, Pereira V, Lopez-Alonso M, Miranda M, Hernandez J (2004) Organic acids as a substitute for monensin in diets for beef cattle. Anim Feed Sci Technol 115:101-116. doi:10.1016/j.anifeedsci.2004.02.001

Canadian Fertilizer Institute - CFI (2009) Statistical documents, www.cfi. ca/Publications/statistical Documents.asp, Cited 27 May 2009

Christopher SF, Lal R (2007) Nitrogen management affects carbon sequestration in North American cropland soils. Crit Rev Plant Sci 26:45-67. doi:1080/07352680601174830 
Clemens J, Trimborn M, Weiland P, Amon B (2006) Mitigation of greenhouse gas emissions by anaerobic digestion of cattle slurry. Agric Ecosyst Environ 112:71-177. doi:10.1016/j. agee.2005.08.016

Desjardins RL, Kulshreshtha SN, Junkins B, Smith W, Grant B, Boehm M (2001) Canadian greenhouse gas mitigation options in agriculture. Nutr Cycl Agroecosyst 60:317-326. doi:10.1023/ A:1012697912871

Dobbie K, Smith KA (2003) Impact of different forms of $\mathrm{N}$ fertilizer on $\mathrm{N}_{2} \mathrm{O}$ emissions from intensive grassland. Nutr Cycl Agroecosyst 67:37-46. doi:10.1023/A:1025119512447

Duke C. (2006) The potential for agricultural greenhouse gas emission reductions in the temperate region of Canada through nutrient management planning, Research Integration Program - Synthesis paper, BIOCAP

Eco-ressources Consultants (2009) Literature review on beneficial management practices related to climate change mitigation and adaptation for Manitoba's agriculture sector, Montreal, QC, pp 61

Ellert BH, Janzen HH (2008) Nitrous oxide, carbon dioxide and methane emissions from irrigated cropping systems as influenced by legumes, manure and fertilizer. Can J Soil Sci 88:207-217. doi:10.4141/CJSS06036

Entz HM, Bullied WJ, Forster DA, Gulden R, Vessey JK (2001) Extraction of subsoil nitrogen by alfalfa, alfalfa-wheat and perennial grass systems. Agron J 93:495-503. doi:10.2134/agronj2001.933495x

Entz HM, Baron VS, Carr PM, Mayer DW, Smith SRJ, McCaughey WP (2002) Potential of forages to diversify cropping systems in the Northern Great Plains. Agron J 94:240-250. doi:10.2134/ agronj2002.0240

Environment Canada (2010) National inventory report part 1 greenhouse gas sources and sinks in Canada, Catalogue no. En81-4/2008E, http://www.ec.gc.ca/ges-ghg, Cited 31 Aug 2010

Ford M, Heyden J, Kuipers A, Ringey R, Westerlund D (2007) Intercropping spring and winter cereals to extend grazing, available on http://www1.agric.gov.ab.ca/\$department/deptdocs. nsf/all/crop12143/\$FILE/RangeForageIntercropping.pdf，Cited 01 Dec 2008

Foster P, Ramaswamy V, Artaxo P, Berntsen T, Betts R, Fahey DW, Haywood J, Lean J, Lowe DC, Myhre G, Nganga J, Prinn R, Raga G, Schulz M, Van Dorland R (2007) Changes in Atmospheric constituents and in radiative forcing. In: Solomon S, Qin D, Manning M, Chen Z, Marquis M, Averyt KB, Tignor M, Miller HL (eds) Climate change 2007: the physical science basis. Contribution of working group I to the fourth assessment report of the intergovernmental panel on climate change. Cambridge University Press, Cambridge, pp 131-217

France J, Kebreab E (2008) Mathematical modelling in animal nutrition. $\mathrm{CAB}$ International, London

Furon AC, Wagner-Riddle C, Smith RC, Warland JS (2008) Wavelet analysis of wintertime and spring thaw $\mathrm{CO}_{2}$ and $\mathrm{N}_{2} \mathrm{O}$ fluxes from agricultural fields. Agric Forest Metrol 148:1305-1317. doi:10.1016/j.agrformet.2008.03.006

Goldemberg J, Guardabassi P (2009) Are biofuels a feasible option? Energy Policy 37:10-14. doi:10.1016/j.enpol.2008.08.031

Grant B, Smith WN, Desjardins R, Lemke R, Li C (2004) Estimated $\mathrm{N}_{2} \mathrm{O}$ and $\mathrm{CO}_{2}$ emissions as influenced by agricultural practices in Canada. Clim Change 65:315-332. doi:10.1023/B: CLIM.0000038226.60317.35

Grant RF, Pattey E, Goddard TW, Kryzanowski LM, Puurveen H (2006) Modeling the effect of fertilizer application rate on nitrous oxide emissions. Soil Sci Soc Am J 70:235-248. doi:10.2136/ sssaj2005.0104

Gregorich EG, Rochette P, VandenBygaart JA, Angers DA (2005) Greenhouse gas contributions of agricultural soils and potential mitigation practices in Eastern Canada. Soil Tillage Res 83:5372. doi:10.1016/j.still.2005.02.009
Hao X, Chang C, Larney FJ (2004) Carbon, nitrogen balances and greenhouse gas emission during cattle feedlot manure composting. J Environ Qual 33:37-44. doi:10.2134/jeq2004.0037

Harper LA, Denmead OT, Freney JR, Byers FM (1999) Direct measurements of methane emissions from grazing and feedlot cattle. J Anim Sci 77:1392-1401

Havens A, Lastiwka G (2008) Demonstration of year round grazing systems utilization BMP's, www.agriresean.qc.ca, Cited 04 Dec 2008

Heichel GH (1980) Assessing the fossil energy costs of propagating agricultural crops. In: Pimental D (ed) Handbook of energy utilization in agriculture. CRC Press, Boca Raton, pp 27-33

Helgason BL, Janzen $\mathrm{HH}$, Chantigny $\mathrm{MH}$, Drury $\mathrm{CF}$, Ellert BH, Gregorich EG, Lemke RL, Pattey E, Rochette P, Wagner-Riddle $\mathrm{C}$ (2005) Toward improved coefficients for predicting direct $\mathrm{N}_{2} \mathrm{O}$ emissions from soil in Canadian agroecosystems. Nutr $\mathrm{Cycl}$ Agroecosyst 72:87-99. doi:10.1007/s10705-004-7358-y

Hindrichsen IK, Wettstein HR, Machmüller A, Soliva CR, BachKnudsen KE, Madsen J, Kreuzer M (2004) Effects of feed carbohydrates with contrasting properties on rumen fermentation and methane release in vitro. Can J Anim Sci 84:265-276. doi:10.4141/A03-095

Hoeppner JW (2001) The effects of legume green manures, perennials forages, and cover crops on non renewable energy use in western Canada cropping systems, Msc Thesis, University of Manitoba, Winnipeg, MB

Huang Q, Wohlgemut O, Cicek N, France J, Kebreab E (2010) A mechanistic model for predicting methane emissions from anaerobic manure storage systems. Can J Soil Sci 90:507-516. doi:10.4141/CJSS09094

Hutchinson JJ, Campbell CA, Desjardins RL (2007) Some perspectives on carbon sequestration in agriculture. Agric For Meteorol 142:288-302. doi:10.1016/j.agrformet.2006.03.030

IPCC (2006) Intergovernmental panel on climate change guidelines for national greenhouse gas inventories. Volume 4: Agriculture, forestry and other land use. Chapter 11: $\mathrm{N}_{2} \mathrm{O}$ Emissions from managed soils, and $\mathrm{CO}_{2}$ Emissions from lime and urea application, http://www.ipcc-nggip.iges.or.jp/public/2006gl/pdf/ 4 Volume4/ V4 11 Ch11 N2O\%26CO2.pdf, Cited 01 Sept 2010

Janzen HH, Desjardins RL, Asselin JMR, Grace B (1998) The health of our air: toward sustainable agriculture in Canada. Agriculture and Agri-Food Canada, Ottawa, p 98

Janzen HH, Angers DA, Boehm M, Bolinder M, Desjardins RL, Dyer JA, Ellert BH, Gibb DJ, Gregorich EG, Helgason BL, Lemke R, Masse D, McGinn SM, McAllister TA, Newlands N, Pattey E, Rochette P, Smith W, VandenBygaart AJ, Wang H (2006) A proposed approach to estimate and reduce net greenhouse gas emissions from whole farms. Can J Soil Sci 86:401-418. doi:10.4141/SO5-101

Jarecki MK, Parkin TB, Chan ASK, Hartfield JL, Jones R (2008) Greenhouse gas emissions from two soils receiving nitrogen fertilizer and swine manure slurry. J Environ Qual 37:1432-1438. doi:10.2134/jeq2007.0427

Jayasundara S, Wagner-Riddle C, Parkin G, von Bertoldi P, Warland J, Kay B, Voroney P (2007) Minimizing nitrogen losses from a corn-soybean-winter wheat rotation with best management practices. Nutr Cycl Agroecosyst 79:141-159. doi:10.1007/ s10705-007-9103-9

Johnson JMF, Franzluebbers AJ, Weyere SL, Reicosky DC (2007) Agricultural opportunities to mitigate greenhouse gas emissions. Environ Pollut 150:107-124. doi:10.1016/j.envpol.2007.06.030

Jongbloed AW, Mroz Z, Kemme PA (1992) The effect of supplementary Aspergillus niger phytase in diets for pigs on concentration and apparent digestibility of dry matter, total phosphorus, and phytic acid in different sections of the alimentary tract. J Anim Sci 70:1159-1168 
Kagan MW (2000) Nitrous oxide distribution in soil and surface flux. Msc Thesis, University of Manitoba, Winnipeg, MB

Kahimba FC, Sri RR, Froese J, Entz M, Nason R (2008) Cover crop effects on infiltration, soil temperature, and soil moisture distribution in the Canadian Prairies. Am J Agric Biol Eng 24:321-333

Kebreab E, Clark K, Wagner-Riddle C, France J (2006) Methane and nitrous oxide emissions from Canadian animal agriculture: a review. Can J Anim Sci 86:135-158. doi:10.4141/A05-010

Kebreab E, Johnson KA, Archibeque SL, Pape D, Wirth T (2008) Model for estimating enteric methane emissions from US cattle. J Anim Sci 86:2738-2748. doi:10.2527/jas.2008-0960

Keyzer MA, Merbis MD, Voortman RL (2008) The biofuel controversy. Economist 156:507-527. doi:10.1007/s10645-008-9098-x

Khakbazan M, Monreal M, Derksen DA, Grant CA, Moulin AP, Zentner RP (2005) The economics, energy use efficiency, and greenhouse gas emissions of high and low inputs used in agriculture: a wheat-pea rotation study. Can J Plant Sci 85:167. doi:10.4141/P04-csabstracts

Khan ZR (2002) Cover crops. Encyclopaedia of Pest Management $1: 155-158$

Kirkpatrick DE, Steen RWJ, Unsworth EF (1997) The effect of differing forage:concentrate ratio and restricting feed intake on the energy and nitrogen utilization by beef cattle. Livest Prod Sci 51:151-164. doi:10.1016/S0301-6226(97)00099-7

Kulshreshtha SN, Junkins B, Desjardins R (2000) Prioritizing greenhouse gas emission mitigation measures for agriculture. Agric Syst 66:145-166. doi:10.1016/S0308-521X(00)00041-X

Kulshreshtha SN, Junkins B, Desjardins R (2001) Mitigation of greenhouse gas emissions from the agriculture and agri-food sector in Canada: a regional perspective. Can J Reg Sci 24:191-220

Lal R (2001) Soil carbon sequestration and the greenhouse effect. SSSA Special Publication, Soil Science Society of America Inc, Madison

Larney FJ, Bullock MS, McGinn SM, Fryrear DW (1995) Quantifying wind erosion on summer fallow in Southern Alberta. J Soil Water Conserv 50:91-95

Lefebvre A, Eilers W, Chunn B (2005) Environmental sustainability of Canadian agriculture: Agri-environmental indicator report \#2. Agriculture and Agri-Food Canada, Ottawa

Lemke RL, Zhong Z, Campbell CA, Zentner R (2007) Can pulse crops play a role in mitigating greenhouse gases from north American agriculture. Agron J 99:1719-1725. doi:10.2134/ agronj2006.0327s

Liebig MA, Morgan JA, Reeder JD, Ellert BH, Gollany HT, Schuman GE (2005) Greenhouse gas contributions and mitigation potential of agricultural practices in northwestern USA and western Canada. Soil Tillage Res 83:25-52. doi:10.1016/j. still.2005.02.008

Luiciuk GM, Bonneau MA, Boyle DM, Viberg E (2007) Carbon sequestration-Additional environmental benefits of forages in the PFRA permanent cover program, http://www4.agri.gc. Cited 28 Nov 2008

Lupwayi NZ, Kennedy AC (2007) Grain legumes in Northern Great Plains: impacts on selected biological soil processes. Agron $\mathrm{J}$ 99:1700-1709. doi:10.2134/agronj2006.0313s

MAFRI (2005) Agriculture: climate friendly farms [Online], available on http://www.gov.mb.ca/asset_library/en/beyond kyoto/agriculture. pdf, Cited 5 Nov 2008

MAFRI (2008) Soil fertility guide [Online], available on www.gov.mb.ca/ agriculture/soilwater/nutrients/fnm02s00.html, Cited 10 Nov 2008

Malhi SS, Lemke R (2007) Tillage, crop residue and N fertilizer effects on crop yield, nutrient uptake, soil quality and nitrous oxide gas emissions in a second 4-yr rotation cycle. Soil Tillage Res 96:269-283. doi:10.1016/j.still.2007.06.011

Malhi SS, Oliver E, Mayerle G, Kruger G, Gill KS (2003) Improving effectiveness of seedrow-placed urea with urease inhibitor and polymer coating for durum wheat and canola. Commun Soil Sci Plant Anal 34:1709-1727. doi:10.1081/CSS-120021307

Malhi SS, Lemke R, Mooleki P, Schoenau JJ, Brandt S, Wang GH, Hultgreen GE, May WE (2008) Fertilizer N management and P placement effects on yield, seed protein content and $\mathrm{N}$ uptake of flax under varied conditions in Saskatchewan. Can J Plant Sci 88:11-33. doi:10.4141/CJPS07042

Matus A, Derksen DA, Walley FL, Loeppky HA, van Kessel C (1997) The influence of inorganic nitrogen fixation in lentil and pea. Can J Plant Sci 77:197-200. doi:10:4141/P96-078

McCaughey WP, Wittenberg K, Corrigan D (1997) Methane production by steers on pasture. Can J Anim Sci 77:519-524

McGinn SM, Beauchemin KA, Coates T, Colombatto D (2004) Methane emissions from beef cattle: effects of monensin, sunflower oil, enzymes, yeast, and fumaric acid. J Anim Sci 82:3346-3356

Mills JAN, Dijkstra J, Bannink A, Cammell SB, Kebreab E, France J (2001) A mechanistic model of whole tract digestion and methanogenesis in the lactating dairy cow: model development, evaluation and application. J Anim Sci 79:1584-1597

Moe PW, Tyrrell HF (1979) Methane production in dairy cows. J Dairy Sci 62:1583-1586. doi:10.3168/jds.S0022-0302(79)83465-7

Mosier AR, Duxbury JM, Freney JR, Heinemeyer O, Minami K, Johnson DE (1998) Mitigating agricultural emissions of methane. Clim Change 40:39-80. doi:10.1023/A:1005338731269

Nkrumah JD, Okine EK, Mathison GW, Schmid K, Li C, Basarab JA, Price MA, Wang Z, Moore SS (2006) Relationships of feedlot feed efficiency, performance, and feeding behavior with metabolic rate, methane production, and energy partitioning in beef cattle. J Anim Sci 84:145-153

Novak SM, Fiorelli JL (2009) Greenhouse gases and ammonia emissions from organic mixed crop-dairy systems: a critical review of mitigation options. Agron Sustain Dev 30:215-236. doi:10.1051/agro/2009031

National Research Council - NRC (2003) Air emissions from animal feeding operations, National Academies, pp 263

Odongo NE, Kramer A, Las JE, AlZahal O, Kerrigan B, Kebreab E, France J, May T, McBride BW (2006) Feeding strategies to minimize the extent of methane output from dairy cows into the environment. Can J Anim Sci 86:595. doi:10.4141/A06-CSASabstracts

Odongo NE, Bagg R, Vessie G, Dick P, Or-Rashid MM, Hook SE, Gray JT, Kebreab E, France J, McBride BW (2007a) Longterm effects of feeding monensin on methane production in lactating dairy cows. J Dairy Sci 90:1781-1788. doi:10.3168/ jds.2006-708

Odongo NE, Or-Rashid MM, Bagg R, Vessie G, Dick P, Kebreab E, France J, McBride BW (2007b) Long-term effects of feeding monensin on milk fatty acid composition in lactating dairy cows. J Dairy Sci 90:5126-5133. doi:10.3168/jds.2007-0242

Odongo NE, Or-Rashid MM, Kebreab E, France J, McBride BW $(2007 \mathrm{c})$ Effect of supplementing myristic acid in dairy cow rations on ruminal methanogenesis and fatty acid profile in milk. J Dairy Sci 90:1851-1858. doi:10.3168/jds.2006-0541

Okine E.K., Basarab J.A., Goonewardene L.A., Mir P., Mir Z., Price M.A., Arthur P.F., Moore S.S. (2003) Residual feed intake-What is it and how does it differ from traditional concepts of feed utilization, Conference proceedings of Can Soc Anim Sci Annual Meeting, Jun 10-13 (16 pages on CD proceedings)

Ominski KH, Boadi DA, Wittenberg KM (2006) Enteric methane emissions from backgrounded cattle consuming all-forage diets. Can J Anim Sci 86:393-400. doi:10.4141/A05-051

Ominski KH, Tenuta M, Krause D, Wittenberg K, Holley R, Entz M, Wilson C, Tremorin D, Walkty J, Stewart S, Coppi L (2008) Best management practices to improve the productivity and environmental sustainability of grassland pasture systems. University of Manitoba, Winnipeg 
Pattey E, Trzcinski MK, Desjardins RL (2005) Quantifying the reduction of greenhouse gas emissions as a result of composting dairy and beef cattle manure. Nutr Cycl Agroecosyst 72:173187. doi:10.1007/s10705-005-1268-5

Philippe FX, Laitat M, Canart M, Vandenheede M, Nicks B (2007) Comparison of ammonia and greenhouse gas emissions during the fattening of pigs, kept either on fully slatted floor or on deep litter. Livest Sci 111:144-152. doi:10.1016/j.livsci.2006.12.012

Pillai UPP, Manoharan V, Lisle A, Li X, Bryden W (2009) Phytase supplemented diets affect soluble phosphorus and nitrogen in manure and manure-amended soil. J Environ Qual 38:17001708. doi: $10.2134 /$ jeq2008.0236

Pinares-Patiño CS, Baumont R, Martin C (2003) Methane emissions by Charolais cows grazing a monospecific pasture of timothy at four stages of maturity. Can J Anim Sci 83:769-777. doi:10.4141/A03-034

Pulse Research Council (2002) Canadian pulse strategic research: building the pulse industry through research, www.specialcrops. mb.ca, Cited 23 Nov 2008

Rejis JW (2007) Improving slurry by diet adjustments: a novelty to reduce $\mathrm{N}$ losses from grassland based dairy farms. $\mathrm{PhD}$ thesis, Wageningen University, The Netherlands

Rochette P, Janzen HH (2005) Towards a revised coefficient for estimating for estimating $\mathrm{N}_{2} \mathrm{O}$ from legumes. Nutr Cycl Agroecosyst 73:171-179

Rochette P, Worth DE, Lemke RL, McConkey BG, Pennock DJ, Wagner-Riddle C, Desjardins RL (2008) Estimation of $\mathrm{N}_{2} \mathrm{O}$ emissions from agricultural soils in Canada. I. Development of a country-specific methodology. Can J Soil Sci 88:641-654. doi: $10.4141 /$ CJSS07025

Rolfe D. (2007) Why are fertilizer prices so high?, http://www. umanitoba.ca/afs/agronomists conf/archived.html MAC Proc from 2000-2007, Cited 07 Nov 2008

Ross SM, Izaurralde RC, Janzen HH, Robertson JA, McGill WB (2008) The nitrogen balance of three long-term agroecosystems on a boreal soil in western Canada. Agric Ecosyst Environ 96:1719-1729. doi:10.1016/j.agee.2008.04.007

Russelle MP, Entz MH, Franzluebbers AJ (2007) Reconsidering integrated crop-livestock systems in North America. Agron J 99:325-334. doi:10.2134/agronj2006.0139

Schils RLM, Verhagen A, Aarts HFM, Kuikman PJ, Sebek LBJ (2006) Effect of improved nitrogen management on greenhouse gas emissions from intensive dairy systems in the Netherlands. Glob Chang Biol 12:382-391. doi:10.1111/j.1365-2486.2005.01090.x

Searchinger T, Heimlich R, Houghton RA, Dong FX, Elobeid A, Fabiosa J, Tokgoz S, Hayes D, Yu TH (2008) Use of US croplands for biofuels increases greenhouse gases through emissions from land-use change. Science 319:1238-1240. doi: $10.1126 /$ science. 1151861

Sheaffer CC, Simmons SR, Schmitt MA (2001) Annual medic and berseem clover dry matter and nitrogen production in rotation with corn. Agron J 93:1080-1086. doi:10.2134/agronj2001.9351080x

Smith WN, Desjardins RL, Grant B (2001) Estimated changes in soil carbon associated with agricultural practices in Canada. Can J Soil Sci 81:221-227. doi:10.4141/S00-033

Smith P, Martino D, Cai Z, Gwary D, Janzen H, Kumar P, McCarl B, Ogle S, O'Mara F, Rice C, Scholes B, Sirotenko O, Howden M, McAllister T, Pan G, Romanenkov V, Schneider U, Towprayoon S, Wattenbach M, Smith J (2008a) Greenhouse gas mitigation in agriculture. Phil Trans Soc B 363:789-813. doi:10.1098/ rstb.2007.2184

Smith WN, Grant BB, Desjardins RL, Rochette P, Drury CF, Li C (2008b) Evaluation of two process-based models to estimate soil $\mathrm{N}_{2} \mathrm{O}$ emissions in Eastern Canada. Can J Soil Sci 88:251-260. doi:10.4141/CJSS06030
Snyder CS, Bruulsema TW, Jensen TL (2007) Greenhouse gas emissions from cropping systems and the influence of fertilizer management-a literature review. International Plant Nutrition Institute, Norcross

Sohi S, Lopez-Capel E, Krull E, Bol R (2009) Biochar, climate change and soil: a review to guide future research, CSIRO Land and Water Science Report 05/09, pp 17-31

Soussana JF, Allard V, Pilegaard K, Ambus P, Amman C, Campbell C, Ceschia E, Clifton-Brown J, Czobel S, Domingues R, Flechard C, Fuhrer J, Hensen A, Horvath L, Jones M, Kasper G, Martin C, Nagy Z, Neftel A, Raschi A, Baronti S, Rees RM, Skiba U, Stefani P, Manca G, Sutton M, Tuba Z, Valentini R (2007) Full accounting of the greenhouse gas $\left(\mathrm{CO}_{2}, \mathrm{~N}_{2} \mathrm{O}, \mathrm{CH}_{4}\right)$ budget of nine European grassland sites. Agric Ecosyst Environ 121:121134. doi:10.1016/j.agee.2006.12.022

Statistics Canada (2004) Fertilizer and pesticide management in Canada, Catalogue no. 21-021-MIE No.003, Ottawa, ON

Statistics Canada (2006) Agriculture: Canada year book 2009, Catalogue n0. 11-402-X, http://www.statcan.gc.ca/pub/11-402-x/ 2009000/pdf/agriculture-eng.pdf, Cited 8 Sept 2010

Statistics Canada (2009) Livestock and aquaculture, Catalogue no. 23015-X, Ottawa, ON

Statistics Canada (2003) Manure storage in Canada, Catalogue no. 21021-MIE. Minister of Industry, Ottawa, p 46

Stehfest E, Bouwman L (2006) $\mathrm{N}_{2} \mathrm{O}$ and $\mathrm{NO}$ emission from agricultural fields and soil under natural vegetation: summarizing available measurement data and modeling of global annual emissions. Nutr Cycl Agroecosyst 74:207-228. doi:10.1007/ s10705-006-9000-7

Stephenson K, Bosch D, Groover G (2004) Carbon credit potential from intensive rotational grazing under carbon credit certification protocols, American Agricultural Economics 2004 Annual Meeting, Aug 1-4, Denver, CO

Stewart AA, Little SM, Ominski KH, Wittenberg KM, Janzen HH (2009) Evaluating greenhouse gas mitigation practices in livestock systems: an illustration of a whole-farm approach. J Agric Sci 147:367-382. doi:10.1017/S0021859609008764

Tanaka DL, Karn JF, Scholljegerdes EJ (2008) Integrated crop/livestock systems research: practical research considerations. Renew Agr Food Syst 23:80-86. doi:10.1017/S1742170507002165

Tenuta M, Beauchamp EG (2003) Nitrous oxide production from granular nitrogen fertilizers applied to a silt loam soil. Can J Soil Sci 83:521-532. doi:10.4141/S02-062

Thelen KD, Fronning BE, Kravchenko A, Min DH, Robertson GP (2010) Integrating livestock manure with a corn-soybean bioenergy cropping system improves short-term carbon sequestration rates and net global warming potential. Biomass Bioenergy 34:960-966. doi:10.1016/j.biombioe.2010.02.004

Thurow TL (2004) Grazing practices, soil conservation. Encyclopaedia of Animal Science 1:1499-1501

Tiessen KHD, Flaten DN, Bullock PR, Burton DL, Grant CA, Karamanos RE (2006) Transformation of fall-banded urea: application date, landscape position, and fertilizer additive effects. Agron J 98:1460-1470. doi:10.2134/agronj2005.0304

University of Manitoba (2006) Cultivar mixtures cover crops, and intercropping with organic spring wheat, http://umanitoba.ca. outreach/naturalagriculture/articles/wheatintercrop.html, Cited 08 Dec 2008

Velthof GL, Kuikman PJ, Oenema O (2003) Nitrous oxide emission from animal manures applied to soil under controlled conditions. Biol Fertil Soils 37:221-230. doi:10.1007/s00374-003-0589-2

Wagner-Riddle C, Thurtell GW (1998) Nitrous oxide emissions from agricultural fields during winter and spring thaw as affected by management practices. Nutr Cycl Agroecosyst 52:151-163. doi:10.1023/A:1009788411566 
Wagner-Riddle C, Furon A, Mclaughlin NL, Lee I, Barbeau J, Jayasundara S, Parkin G, von Bertoldi P, Wardland J (2007) Intensive measurement of nitrous oxide emissions from a cornsoybean-wheat rotation under two contrasting management systems over 5 years. Glob Chang Biol 13:1722-1736. doi:10.1111/j.1365-2486.2007.01388.x

Wagner-Riddle C, Hu QC, van Bochove E, Jayasundara SWJ (2008a) Linking nitrous oxide flux during spring thaw to nitrate denitrification in the soil profile. Soil Sci Soc Am J 72:908916. doi:10.2136/sssaj2007.0353

Wagner-Riddle C, Kebreab E, France J, Rapai J (2008b) Supporting measurements required for evaluation of greenhouse gas emission models for enteric fermentation and stored animal manure. In: France J, Kebreab E (eds) Mathematical modelling in animal nutrition. CAB International, Walligford, pp 204-224

Walburger MA, Le Roy D, Kaushik KK, Klein KK (2006) Policies to stimulate biofuel production in Canada: Lessons from Europe and the United States, A BIOCAP Research Integration Program, Synthesis paper, pp.63. www.biocap.ca, Cited 12 Mar 2009

Walters DT (2005) Fertilizer nitrogen source and management impacts on greenhouse gas emissions, In: Proc 21st North Central
Industry and Extension Soil Fertility Conference 16-17 Nov 2005, Des Moines, IA Potash and Phosphate Inst, Brookings, SD

West TO, Post WM (2002) Soil organic carbon sequestration rates by tillage and crop rotation: a global data analysis. Soil Sci Soc Am J 66:1930-1940. doi:10.2136/sssaj2002.1930

Wittenberg KM, Boadi DA (2001) Reducing greenhouse gas emissions through feeding and grazing management, Public Consultation Sessions. University of Manitoba, Winnipeg

Yates AG, Bailey RC, Schwindt JA (2007) Effectiveness of best management practices in improving stream ecosystem quality. Hydrobiologia 583:331-344. doi:10.1007/s10750-007-0619-4

Yitbarek A, Tenuta M, Nyachoti CM, France J, Kebreab E (2009) Effect of phytase supplementation on greenhouse gas emissions from manure application. Can J Anim Sci 89:170

Zaman M, Nguyen ML, Blennerhassett JD, Quin BF (2008) Reducing $\mathrm{NH}_{3}, \mathrm{~N}_{2} \mathrm{O}$ and $\mathrm{NO}_{3}{ }^{-}-\mathrm{N}$ losses from a pasture soil with urease or nitrification inhibitors and elemental S-amended nitrogenous fertilizers. Biol Fertil Soils 44:693-705. doi:10.1007/s00374-007-0252-4

Zentner RP, Campbell CA, Biederbeck VO, Miller PR, Selles F, Fernandez MR (2001) In search of a sustainable cropping system for the semiarid Canadian Prairies. J Sustain Agr 18:117-136. doi:10:1300/J064v18n02_10 